\title{
Passive reclamation of soft-sediment ecosystems on the North Coast of British Columbia, Canada
}

Article

Accepted Version

Creative Commons: Attribution-Noncommercial-No Derivative Works 4.0

Campbell, L., Sizmur, T., Juanes, F. and Gerwing, T. G. (2019) Passive reclamation of soft-sediment ecosystems on the North Coast of British Columbia, Canada. Journal of Sea Research, 155. 101796. ISSN 1385-1101 doi:

https://doi.org/10.1016/j.seares.2019.101796 Available at https://centaur.reading.ac.uk/88167/

It is advisable to refer to the publisher's version if you intend to cite from the work. See Guidance on citing.

To link to this article DOI: http://dx.doi.org/10.1016/j.seares.2019.101796

Publisher: Elsevier

All outputs in CentAUR are protected by Intellectual Property Rights law, including copyright law. Copyright and IPR is retained by the creators or other copyright holders. Terms and conditions for use of this material are defined in the End User Agreement.

www.reading.ac.uk/centaur 
Central Archive at the University of Reading

Reading's research outputs online 
3 Lily Campbel11*, Tom Sizmur2, Francis Juanes1, Travis G Gerwing1,3

4 1Department of Biology, University of Victoria. Victoria, British Columbia, Canada.

$5 \quad 2$ Department of Geography and Environmental Science, University of Reading. Reading, UK.

63 Ecosystem Science and Management Program, University of Northern British Columbia. Prince

7 George, British Columbia, Canada.

$9 \quad *$ Corresponding Author: Lily Campbell. Email: lilyncampbell@gmail.com

\section{Abstract} habitat suitability for biological communities. The Skeena River estuary (British Columbia, Canada) is undergoing passive reclamation from historical salmon canneries and pulp mills, while localized disturbances continue at present. To reveal both current impacts and the trajectory of passive reclamation from historical activities, the intertidal mudflat surrounding the longest operating salmon cannery, Cassiar Cannery, within the Skeena estuary was surveyed. Nutrient availability (chlorophyll $a$ concentration/organic matter content), sediment variables (particle size, water content, penetrability, woody debris/macroalgae cover, apparent redox potential discontinuity depth), and infaunal community composition varied spatiotemporally, and suggest that an old dock may be influencing the infaunal community given the abundance of disturbance indicating taxa below the dock. However, with populations of amphipods, mobile polychaetes, and a complex community structure, the mudflat as a whole appears to be relatively healthy. Therefore, cessation of historic activities has allowed for passive reclamation to a reasonably unstressed state, though a threshold of recovery may exist for intertidal mudflats beyond which passive reclamation will not be effective.

Key Words: Infauna, Intertidal, Habitat Disturbance, Passive Restoration, Salmon Cannery, Soft- 


\section{Introduction}

Soft-sediment ecosystems represent over $70 \%$ of coastal ecosystems, and are important

components of estuarine habitats (Constable and Fairweather 1999; Schlacher and Thompson 2013).

Estuaries are productive regions with importance for commercial fisheries, providing habitat for sensitive species (especially migratory shorebirds), as well as recreational uses for human populations (Carr-Harris et al. 2015; Constable and Fairweather 1999; Dissanayake et al. 2018; Kennish 2002). However, urbanization and industrial development have resulted in the degradation of soft-sediment ecosystems and estuaries (Constable and Fairweather 1999; Crain et al. 2008; Kennish 2002; Schlacher et al. 2016). Coastal developments will increase as human populations grow, with the associated habitat degradation leading to substantial ecological consequences (Dissanayake et al. 2018; Kritzer et al. 2016). As such, understanding human impacts and subsequent management is now a fundamental depletion and anoxia (Buttermore 1977; Kristensen 2000; Levin et al. 2009; Waldichuk 1979). Such enrichment can also lead to sulphide accumulation, altering infaunal communities through toxicological 
contamination is not restricted to organic enrichment and occurs through pollution and industrial

54

55

56

57

58

60

61

62

63

64

65

66

67

68

effluents containing polycyclic aromatic hydrocarbons, sulfides, coppers and other chemicals (Hoos 1975; Turner 2019; Yunker et al. 2002), with negative impacts on infaunal communities (Pires et al. 2017; Pocklington and Wells 1992; Waldichuk 1966).

Due to their well-understood responses to disturbance, invertebrates are invaluable for evaluating ecosystem health and identifying disturbed habitats (Gesteira and Dauvin 2000; GuerraGarcia and Garcia-Gomez 2004; Pearson and Rosenberg 1978). Invertebrates have been used to develop ecological theories on organismal responses to disturbance (Cowie et al. 2000; Gerwing et al. 2017a; Pearson and Rosenberg 1978), and are employed in both monitoring and assessing human impacts on natural ecosystems (Borja and Muxika 2005; Gerwing et al. 2018a; Hereward et al. 2017; Muxika et al. 2005; Pearson and Rosenberg 1978). In addition to monitoring applications, marine benthic invertebrates support commercial fisheries, both by serving as dietary sources for fish and as industrial bait (Davis et al. 2014; Kritzer et al. 2016; Pires et al. 2017). Therefore, studying invertebrates is a pro-active strategy to detect disturbances before productivity of commercial fisheries is impaired (Ozdemir et al. 2011; Pinto et al. 2009). In soft-sediment ecosystems, infaunal invertebrates have been employed as successful indicators for multiple disturbance mechanisms including organic enrichment, hypoxia, and pollution (Bett 1988; Pearson and Rosenberg 1978; Thrush et al. 2003). Although disturbance can have detrimental effects, soft-sediment ecosystems and infaunal communities are resilient to disturbance as the fauna are exposed to extreme variability on a daily basis (Altieri 2006; Cowie et al. 2000; Gerwing et al. 2018a; Valdivia et al. 2011), and are responsive to passive reclamation through both physical and biological processes such as wave action, sediment deposition, and bioturbation (Dernie et al. 2003; Gerwing et al. 2018a; Skilleter 1996). Passive reclamation is the cessation of activities causing ecosystem degradation, thus allowing for unassisted recovery (Benayas et al. 2009; Holl and Aide 2011). Considered to be the first and most crucial step in ecological reclamation, passive reclamation can be highly effective in coastal and estuarine ecosystems 
without the associated cost of active reclamation; however, not all reclamation efforts track progress against recovery targets, or consider infaunal communities (Bayraktarov et al. 2016; Holl and Aide 2011; Kauffman et al. 1997; Marquiegui and Aguirrezabalaga 2009; McCrackin et al. 2017). Along the North Coast of British Columbia (BC) Canada, the Skeena River estuary has experienced a variety of disturbances, including physical disruption of soft-sediment, organic enrichment, and accumulation of toxins (Carr-Harris et al. 2015; Gerwing et al. 2018c). Near the mouth of the Skeena River, the mudflat surrounding Cassiar Cannery in Inverness Passage (Figure 1) experiences physical disturbance to the sediment from logs that are transported down the Skeena River, flow through Inverness Passage, and accumulate on the mudflat, while an old dock structure may addition to these current impacts, this mudflat has also been undergoing passive reclamation from historical activities. Established in 1889, Cassiar Cannery was the longest consecutively operating salmon cannery on BC's coast before closing in 1983, with associated disturbances including toxic inputs like copper and creosote, and organic enrichment from discarded salmon carcasses (Beyer et al. 1975; Faggetter 2008; Stone et al. 1981). Furthermore, through the 1900s, 12 salmon canneries operated near the mouth of the Skeena River, with the last cannery ceasing operation in 1989, while pulp mill operations commenced in the 1970s and continued through 2001(Akenhead 1992; Faggetter 2008; Yunker et al. 2002). Unfortunately, estuarine and coastal ecosystems may require at least 15-25 years to recover from degradation spanning a century, or alternatively may never recover and instead exist in a perpetual alternate state (Borja et al. 2010; McCrackin et al. 2017; Simenstad et al. 2006). Therefore, considering historical impacts is crucial when assessing estuary health and ecosystem functioning (Szabo 2010).

At the Cassiar Cannery mudflat, the sediment is predominantly fine silt $(<63 \mu \mathrm{m})$ and finegrained sand $(125-250 \mu \mathrm{m})$ with coarser grain sand and pebbles present within small patches. A 1-3mm layer of oxic mud occurs at the sediment surface (Gerwing et al. 2017a; McLaren 2016). The mudflat 
was sampled at four distinct locations (Figure 1), with two locations considered impacted (hereafter referred to as Resort and Dock locations) and two chosen as reference stations. As both the Resort

105 Location and Dock Location are within the historical footprint of the salmon cannery, they were thus historically impacted via chemicals such as creosote, copper and copper soldering products, pyrogenic

107 polycyclic aromatic hydrocarbons, grease and other chemicals (Faggetter 2008; Page et al. 1999).

108 Substantial nutrient inputs also occurred due to salmon carcass discards (Beyer et al. 1975; Stone et al. 109 1981). The Dock Location (DL) is situated below the historical wooden dock and is hypothesized to be 110 currently impacted by the dock depositing woody debris on the mudflat surface. Additionally, the 111 benthos below the dock has not seen direct sunlight for 130 years, and sedimentation and hydrology 112 are likely affected by the physical structure of the dock. The Resort Location (RL) is in front of former homes of cannery managers that have been restored to heritage houses, allowing Cassiar Cannery to

114 continue operating as an ecotourism resort. This study does not examine impacts of the resort itself, but

115 instead looks at the current physical disturbance to the sediment surface that occurs at the Resort

116 Location from accumulated logs that flow from the Skeena River through Inverness Passage and scour 117 the sediment surface (Gerwing et al. 2015a; Herbert et al. 2009). decreasing the availability of reference locations within the immediate region that reflect unimpacted soft-sediment ecosystems. The reference locations employed (North Reference (NR) and South Reference (SR)) are both outside the area of current impacts of physical disturbance from logs and the dock structure, and are also outside the historical footprint of the salmon cannery. Due to high tidal

123 flushing, as well as water and sediment input from the Skeena and Nass Rivers (McLaren 2016) any 124 organic matter or chemicals present would likely have been diluted and had minor impacts upon the reference locations (Beyer et al. 1975). Therefore, these locations are adequate reference locations

126 (Underwood 1994; 1997; 2009). 

organic enrichment and physical disturbance from potential woody debris deposition and log scour at the intertidal mudflat surrounding Cassiar Cannery, while also considering historical impacts and the trajectory of passive reclamation. To accomplish these goals, the infaunal community, sediment

131 parameters and nutrient availability were examined at reference and potentially impacted locations.

132 Within the infaunal community, high abundances of indicator taxa including oligochaetes, nematodes, and polychaetes from the families Spionidae and Capitellidae may indicate impacted habitat, as these taxa are often found in higher abundances in disturbed habitats (Chollett and Bone 2007; Pearson and Rosenberg 1978), and these were thus hypothesized to be present at higher abundances at the Dock and Resort Locations. Conversely, taxa indicating healthy habitats such as amphipods and mobile, errant polychaetes were expected to be absent from disturbed locations (Cardoso et al. 2007; Gesteira and Dauvin 2000). The dock was also expected to decrease the depth to the apparent redox potential discontinuity depth (aRPD), due to increased oxygen consumption during decomposition of woody debris, with a subsequent increase in organic matter content at the Dock Location (Kristensen 2000;

141 Pearson and Rosenberg 1978). Impacted locations were also expected to have reduced primary productivity due to disruption to biotic structures and the dock reducing light availability. A greater understanding of passive reclamation and its efficacy would help to inform cost-benefit decisions of coastal management and reclamation activities, given the high costs associated with active reclamation.

\section{Methods}

\subsection{Sampling Scheme and Field Methods}

At each location three transects were established, stretching from the start of the mudflat to the

149 low tide waterline (Cox et al. 2017; Gerwing et al. 2015b). Transects were 60m long, placed 10m apart, 150 and stratified into three equal zones based upon distance from shore (near, middle, far). Within each 151 zone, a $1 \mathrm{~m} 2$ quadrat was randomly selected and established ( $\mathrm{n}=3$ per transect, 9 per location). All 4 
152 locations were sampled in a day, 3 times throughout the summer of 2017 (May 30, June 21, and July

153 20) at the lowest low tides (Cox et al. 2017; Gerwing et al. 2017a) for a total of 27 sampling events per

154 location.

155 At each $1 \mathrm{~m} 2$ quadrat, infauna was collected with a core of $10 \mathrm{~cm}$ in length and a diameter of

$1567 \mathrm{~cm}$. Following collection, the sediment was passed through a $250 \mu \mathrm{m}$ sieve and stored in vials of $95 \%$

157 ethanol (Bringloe et al. 2013; Gerwing et al. 2017a; Hamilton et al. 2003; Sizmur et al. 2013). Forty

158 infaunal taxa have previously been identified at the Cassiar Cannery (Gerwing et al. 2017a; Gerwing et

159 al. 2018c), and specimens were identified to the lowest possible taxonomic unit (Gerwing et al. 2017a;

160 Thrush et al. 2003) as follows: cumaceans, amphipods, polychaetes, nemerteans and bivalves were

161 identified to species; chironomids (larvae) to family; copepods to order; ostracods to class; and 162 nematodes to phylum.

163 For sediment parameters, surface wood cover (\%) and macrophyte cover (\%) of the quadrat 164 were visually estimated, and sediment penetrability was assessed by dropping a metal weight $(15 \mathrm{~cm}$ 165 long, $1.9 \mathrm{~cm}$ diameter, $330 \mathrm{~g}$ ) from a height of $0.75 \mathrm{~m}$ above the sediment (Gerwing et al. 2015b). The 166 depth the weight penetrated the sediment was measured as an indication of how easily water and 167 animals can penetrate the sediment, therefore generating an index that can be compared between 168 quadrats and locations. Additionally, water content, and volume weighted mean particle size in the 169 upper $1 \mathrm{~cm}$ of sediment were quantified as outlined in Gerwing et al. (2015b) by collecting a sediment 170 core $(4.5 \mathrm{~cm}$ diameter, $5 \mathrm{~cm}$ length) from each quadrat. The top $1 \mathrm{~cm}$ of each core was weighed, placed 171 in a drying oven at $1100 \mathrm{C}$ for 12 hours, and re-weighed. Percent water-content was calculated as: 172 
175 Volume-weighted mean particle-size of the sediment for each sample was determined using a Malvern

176 Mastersizer 2000 (www.malvern.com). Particle size was measured in triplicate and a mean value per

177 sample calculated (Gerwing et al. 2015b).

178

179

Depth of the apparent redox potential discontinuity (aRPD) was measured to the nearest $1 \mathrm{~mm}$

180

181

182

183

184

185

186

187

188

189

190

191

192

193

194

195

196

197

198

199

as an index of sediment dissolved oxygen content (Gerwing et al. 2017b; Gerwing et al. 2015c). aRPD

depth gives a relative measure of sediment dissolved oxygen content and redox conditions. The aRPD was measured in the sediment void left by the removal of the $7 \mathrm{~cm}$ diameter infauna core (Gerwing et al. 2013).

Organic matter content was quantified from the sediment core as outlined by Gerwing et al. (2015b). Briefly, dried sediment samples were ashed in a muffle furnace at 5500C for four hours and re-weighed. Percent organic-content was calculated as:

(mass dry sediment - mass of ashed sediment)/(mass of dry sediment) x 100

Chlorophyll $a$ concentration was used as a proxy for the abundance of benthic diatoms (Coulthard and Hamilton 2011; Hargrave et al. 1983; Trites et al. 2005). A 2cm diameter core was taken to determine the concentration of chlorophyll $a$ in the top $2-3 \mathrm{~mm}$ of sediment as outlined by Coulthard and Hamilton (2011). Briefly, chlorophyll pigments were extracted from sediment samples via buffered acetone (90\%) and processed through a spectrophotometer to assess reflectance of chlorophyll pigments (664 and 750nm)

\subsection{Statistical Analysis}

The Permutational Multivariate Analysis of Variance (PERMANOVA) package in the statistical program PRIMER 7 (McArdle and Anderson 2001; Clarke and Gorley 2015) was used to 
elucidate how biotic and abiotic parameters varied between reference and impacted locations. These parameters were divided into infaunal community (species composition and abundance), sediment

202

203

204

205

206

207

208

parameters (depth to the aRPD, sediment water content, volume weighted mean particle size, penetrability, \% macroalgae coverage, and \% wood coverage), and nutrient variables (chlorophyll $a$ concentration and sediment organic matter). Groups of variables were then analyzed separately, to elucidate any differences between reference and potentially impacted areas.

Infaunal abundances were fourth root (x 1/4) transformed to decrease the importance of very abundant species on the outcome of analyses and improve the assessment of less common species. Subsequently, Bray-Curtis distances were used to create a resemblance matrix (Clarke et al. 2006) for the PERMANOVA. Within this PERMANOVA, Location (4 levels), and Sampling Date (3 levels) were fixed factors, while Transect nested within Location (Transect(Location); 3 levels) was a random factor. Four a priori planned contrasts examined how locations varied from each other as follows: 1) Dock Location (DL) vs. reference locations (NR + SR); 2) Resort Location (RL) vs. reference locations (NR + SR); 3) DL vs. RL; and 4) NR vs. SR. An $\alpha$ of 0.05 denotes statistical significance for all analyses. A PERMANOVA was also run to determine if taxonomic richness varied between impacted and reference locations, by summing the number of taxa observed at each quadrat, with Bray-Curtis distances for the resemblance matrix. Taxonomic richness was used as not all specimen could be identified to species, therefore richness is not a true measure of species richness, instead it measures the number of observed taxa (Gerwing et al. 2016; Gerwing et al. 2015b).

For the sediment PERMANOVA, depth to the aRPD, volume-weighted mean sediment size, $\%$ macroalgae cover and $\%$ wood cover were square root $(\sqrt{\mathrm{x}})$ transformed to correct for skewed distributions. For the nutrient matrix, all variables were square root $(\sqrt{\mathrm{x}})$ transformed. All variables were normalized, and Euclidean distances were used to calculate a resemblance matrix. Factors and planned contrasts for both the sediment and nutrient PERMANOVA were as described above in the 
infauna PERMANOVA. Sediment variables also had an a priori analysis conducted for Date X

225

226

227

228

229

230

231

232

233

234

235

236

237

238

239

240

Location comparisons.

Similarity Percentages analyses (SIMPER; Clarke 1993) were used to examine the contribution of each variable (infaunal, sediment or nutrient) to the observed differences between locations or sampling dates. Increased percent dissimilarity indicates increased dissimilarity between locations. The ratio of each variable's average dissimilarity to the standard deviation of dissimilarities (Diss/SD) for infauna, or average squared Euclidean distance to the standard deviation of squared distances (Sq.Dist/SD) for sediment and nutrient variables were calculated. These values represent how consistently each variable contributed to the observed difference; variables with a ratio greater than 1 consistently contributed whereas those with a value below 1 did not (Gerwing et al. 2015b). Finally, non-metric multidimensional scaling (nMDS, 100 restarts) plots were used to visualize variation in infauna, sediment conditions, and nutrient availability between locations. All nMDS graphs had a stress of $\sim 0.2$, and were considered to be good two-dimensional representations (Clarke 1993).

\section{Results}

Analysis of the invertebrate community and sediment variables through PERMANOVAs showed statistically significant spatiotemporal variation, while nutrient availability varied significantly through time (Figures 2-3; Tables 1-2; Supplemental Material Tables 1-3). Both the infauna community and sediment parameters varied significantly between impacted locations (Dock and Resort Locations) and reference locations (North and South Reference; Table 1). Percent dissimilarity of the infaunal community between locations varied between 44 and 52\% (Table 3). A large proportion of the variation in dissimilarity of location comparisons was driven by four taxa: Oligochaeta, Pygospio elegans, Capitella Species Complex and Nematoda (40-45\%; Table 3). However, taxa contributing to observed differences between locations varied. Nematoda, Oligochaeta, and P. elegans were consistently more abundant at DL (7.00, 5.55 and 6.08 individuals $/ \mathrm{m} 2$ respectively) compared to 
reference locations $\left(6.10,3.23\right.$ and 4.71 individuals $\left./ \mathrm{m}_{2}\right)$, but these taxa were consistently higher at reference locations compared to RL (4.74, 1.07 and 4.57 individuals/m2). Furthermore, Capitella Species Complex was consistently higher at reference locations (5.49 individuals $/ \mathrm{m}_{2}$ ) than either disturbed location (3.71 and 3.70 individuals/m2) (Table 3). The amphipod Americorophium salmonis was present at higher abundances in reference locations compared to the Dock Location (4.76 Vs 2.66), but at lower abundances compared to the Resort Location (4.82) (Table 3). The errant polychaete Eteone californica was also present in high abundances at each location with average abundances at DL, RL, and the reference locations being 2.49, 2.90 and 4.07 respectively. Taxonomic richness did not vary significantly with either location or date ( $p=0.5298$ and 0.0950 respectively; Table 1$)$.

A significant interaction was found for Date and Location factors of sediment parameters, therefore a priori contrasts were conducted for each location and sampling date comparison. Sediment properties varied significantly for all location comparisons, except between reference locations (NR vs SR; Table 2). Wood cover contributed the most to location comparisons including DL; however it only consistently contributed for the June 21 sampling date as shown by the Sq.Dist/SD ratio greater than 1 (Table 4). No other trend was observed, and average squared distance for location comparisons ranged from 12.29-14.42.

Nutrient availability had significant differences between sampling dates $(p=0.0002)$, but with no observed effect of location on availability (Table 1). Neither chlorophyll $a$ concentration nor organic matter content consistently contributed to the differences between sampling dates (Table 5). Average squared distance between sampling dates was between 2.28 and 5.18 .

\section{Discussion} Cannery may be impacted from current disturbances including physical disruption of the sediment from 
undergoing passive reclamation from historical impacts associated with salmon canneries and a pulp

275

276

277

278

279

280

281

282

283

284

285

286

287

mill. Therefore, the objective of this study was to examine current impacts while considering historical impacts in the region with regards to the infaunal community, sediment conditions, and nutrient availability.

\subsection{Infaunal Community}

With regards to community composition, there was conflicting evidence of disturbance and of overall health at different spatial scales. The infaunal community exhibited significant spatiotemporal variation, with the presence of oligochaetes, nematodes, and polychaetes from the families Spionidae and Capitellidae, as well as low abundances of amphipods indicative of current or historic disturbances (Chollett and Bone 2007; Keats et al. 2004; Kesaniemi et al. 2012; Pearson and Rosenberg 1978). The infaunal community under the dock (DL) was characterized by higher abundances of oligochaetes, nematodes, and Spionidae polychaetes when compared to the reference locations, as well as by smaller populations of amphipods. Furthermore, DL had an increased abundance of Nippoleucon hinumensis than reference areas which could be indicative of disturbance, as $N$. hinumensis is an invasive cumacean from Asia (Light and Smith 2007) and disturbance can facilitate biological invasions (Burke and Grime 1996; Smith and Knapp 1999). These community characteristics are all representative of a disturbed habitat, and it is unsurprising that the dock is altering the infaunal community composition beneath it. Conversely, the mudflat in front of the ecotourism resort (RL) had smaller populations of oligochaetes, nematodes, and Spionidae and Capitellidae polychaetes, as well as higher populations of amphipods when compared to reference locations. As such, there is no evidence that the mudflat in front of the ecotourism lodge (RL) is negatively impacted by log scour or by the activities of the lodge itself. Moreover, no differences in taxonomic richness were revealed between impacted or reference locations, further suggesting that the potentially disturbing agents occurring at the Cassiar Cannery are not impacting the mudflat. 

when compared to the dock (DL) and resort (RL) locations. This was unexpected, as Capitellidae polychaetes can be indicative of disturbance, particularly of organic enrichment that was expected to 302 occur under the dock structure (Pearson and Rosenberg 1978). However, and as discussed in detail below, no organic enrichment under the dock was observed. Further, Capitellidae polychaete abundance in all locations on the Cassiar Cannery mudflat were similar to those observed on non305 organically enriched mudflats in the region (Campbell, Unpublished Data) as well as on mudflats on the Atlantic coast (Gerwing et al. 2015b). Therefore, Capitellidae polychaetes were within normal abundances when considering the scale of the entire mudflat.

Beyond contrasting different locations within the Cassiar Cannery mudflat, some inferences can be made regarding the overall health of this mudflat. First, all locations had high populations of mobile errant polychaetes and amphipods. Amphipods and mobile errant polychaetes are powerful indicator species (Cardoso et al. 2007; Conlan 1994; Gerwing et al. 2018a; Gerwing et al. 2018b; Gesteira and Dauvin 2000; Thomas 1993), whose high densities throughout this mudflat suggest that the Cassiar 313 Cannery mudflat is relatively healthy. Additionally, complex community structure with multiple species present at all levels of the food web, coupled with high biodiversity is also often representative of relatively undisturbed and/or functional habitats (Pearson and Rosenberg 1976; Pearson and Rosenberg 1978). With high biodiversity, and a complex community across trophic levels, the Cassiar Cannery mudflat has a diverse and functioning food web and as such the community structure is similar to undisturbed mudflats (Cardoso et al. 2007; Gerwing et al. 2015b; Gesteira and Dauvin 2000; Hooper et al. 2005).

While at the scale of the mudflat, Cassiar Cannery may be relatively healthy and functional, community composition at the spatial scale of the $1 \mathrm{~m} 2$ quadrat offers a slightly contradictory perspective. Invasive Cumacea, Capitellidae and Spionidae polychaetes, oligochaetes, and nematodes were observed in some quadrats in all locations at densities indicative of disturbance (Chollett and 
324 Bone 2007; Keats et al. 2004; Kesaniemi et al. 2012; Pearson and Rosenberg 1978). While this could

325 be the result of natural variability, previous investigations of infaunal community composition along

326 BC's north coast have detected remnant signals of historical disturbances within relatively healthy

327 mudflats decades after disturbance (e.g. logging practices (Gerwing et al. 2018b)). It is hypothesized

328 that a similar phenomenon may have been observed here. Within Inverness Passage, 3 salmon

329 canneries besides Cassiar were operating, and another 8 operated around the mouth of the Skeena River

330 (Hoos 1975). Furthermore, a pulp mill in the region discharged highly toxic effluents and spent sulfite

331 liquid (500 tons/day) into the nearshore environment commencing in the 1970s (Hoos 1975; Waldichuk

332 1966; Wilkes and Dwernychuk 1991). The decomposition of the spent sulfite liquid led to greatly

333 reduced biological oxygen demand, and the effluent accumulated in a three-meter thick layer of toxic

334 sludge on the littoral zone near the discharge pipe. Although the discharge pipe was moved in the early

335 1990s before the mill ceased operations in 2001, much of the invertebrate community was defaunated

336 by effluents (Akenhead 1992; Hoos 1975; Waldichuk 1966). Therefore, while the Cassiar Cannery

337 mudflat is now overall relatively healthy, biological signals of disturbance at the scale of the $1 \mathrm{~m} 2$

338 quadrat may be remnants of the historical disturbances this mudflat has experienced. Cessation of

339 disturbances associated with the pulp mill and canneries would have allowed for the process of passive

340 reclamation, which appears to have been relatively successful for this infaunal community.

\section{$342 \quad 4.2$ Sediment Parameters}

343 Sediment parameters varied significantly through time and space, including in comparisons

344 between impacted and reference locations, but no variable consistently contributed to location

345 differences. Wood cover had the largest percent contribution for all comparisons including the Dock

346 Location (18.9 - 27.0\%), but only consistently contributed for one sampling date (June 21). It was

347 hypothesized that the accumulation of woody debris at DL would decrease the depth to the aRPD as

348 oxygen is consumed during the degradation of woody debris. However, this was not observed and may 
be due to tidal flushing either replenishing oxygen consumed in decomposition or removing woody debris before it has sufficient time to decompose (Kristensen 2000). Evidence suggests the latter, as organic matter content was not significantly higher at DL compared to the other locations. Interestingly, DL was the only location that had no macroalgae cover for any quadrat on any sampling date (Supplemental Material Table 2), which may indicate that the dock structure is affecting the hydrology and light availability at the Dock Location.

As physical disturbance can disrupt the redox potential discontinuity and result in water accumulation in associated pits and furrows (Dernie et al. 2003), changes to the aRPD depth and water content were potential indicators of physical disturbance at the Resort Location due to scour by logs.

However, this was not observed in this location, as neither the aRPD depth nor water content consistently contributed to differences in sediment variables between RL and other location comparisons. Additionally, mudflats show high spatiotemporal variation in their sediment parameters (Gerwing et al. 2015b), suggesting that the variability present on this mudflat may not be a result of current or historical impacts.

\subsection{Nutrient Availability}

Although the biological community and sediment conditions showed significant spatiotemporal variation, nutrient availability (chlorophyll $a$ concentration and percent organic matter) only showed temporal variation. Both chlorophyll $a$ and organic matter content are known to vary through time, so temporal differences were not surprising (Gerwing et al. 2015b; Hargrave et al. 1983; Trites et al. 2005). However, a lack of spatial variation was unexpected. As the Dock Location receives no direct sunlight, it was hypothesized to have the lowest chlorophyll $a$ concentration, yet this was not observed.

371 Some species of microalgae can acclimatize to shade (Katayama et al. 2018), and cyanobacteria can 372 produce more chlorophyll $a$ at low light intensities compared to high light intensities (Muller et al. 373 1993; Raps et al. 1983). It is possible that these shade-acclimatized primary producers may be driving 
chlorophyll $a$ productivity at DL, or tidal transport of diatoms to the substrate surface may be occurring

375

376

377

378

379

380

381

382

383

384

385

386

387

388

389

390

391

392

393

394

395

396

397

398

under the dock. Regardless, future work should address how disturbance can influence species

composition of photosynthetic organisms on intertidal mudflats. Additionally, as physical disruption to sediment can be detrimental to a variety of biotic parameters besides infaunal community composition (Dernie et al. 2003; Fonseca et al. 1982; Hansen and Skilleter 1994) it was expected that the Resort Location would have reduced chlorophyll $a$ concentration compared to the reference locations; however, this was not supported by the data.

While the physical disturbance at RL was not expected to alter organic matter content (Dernie et al. 2003), the dock and potential accumulation of wood fibres was expected to result in organic matter enrichment at DL, and the historic cannery may have led to organic matter enrichment compared to the reference locations. This was not observed, suggesting that if organic enrichment occurred, it has decreased over the past 25 years. Additionally, the average organic content in any location was not higher than non-organically enriched mudflats on the east coast of Canada ( 2.2-4.5\%; (Gerwing et al. 2015b) it was marginally higher than at other mudflats nearby, as well as within the disturbed Kitimat Estuary (1.81-3.97\%; Campbell, Unpublished Data; Gerwing et al. 2018a). Future research should determine natural ranges of organic matter content at Northeast Pacific mudflats not experiencing anthropogenic nutrient inputs.

\subsection{Passive Reclamation}

Passive reclamation can be highly effective in coastal and estuarine systems (Bayraktarov et al. 2016; Holl and Aide 2011; Marquiegui and Aguirrezabalaga 2009), while the associated costs of active reclamation can be extremely high (Bayraktarov et al. 2016; Holl and Aide 2011). Additionally, there is no clear relationship between the cost of reclamation and the success of marine coastal reclamation efforts (Bayraktarov et al. 2016). At the Cassiar Cannery mudflat, quantifiable comparisons were not possible due to a lack of pre-disturbance data, but the cessation of 
historical activities would have allowed for passive reclamation. These findings suggest that passive reclamation was sufficient to return this intertidal mudflat to a relatively productive, functional and

401 diverse ecosystem, therefore in some scenarios passive reclamation may be an effective reclamation 402 tool without the burden of high operating costs (Holl and Aide 2011). However, in this study passive 403 reclamation did not restore the community to an entirely unstressed state, as evidenced by locally 404 abundant populations of Capitellidae/Spionidae polychaetes and invasive cumaceans. Therefore, more 405 time may be necessary for further progression towards an unstressed state, or a threshold may exist 406 beyond which intertidal mudflats cannot be reclaimed through passive means. For instance, it is unlikely that an invasive species will passively die off once established.

The Cassiar Cannery mudflat would also have been impacted by chemical contaminants during its operation, and while this study did not quantify residual contaminants (e.g. copper or polycyclic aromatic hydrocarbons from the historical pulp mill and salmon cannery,) Sizmur et al. (In Press) showed no evidence of sediment contamination by potentially toxic elements (a naturally occurring element that can be toxic in high concentrations, e.g, arsenic, cadmium, cobalt, chromium, nickel, lead, and zinc) in the top $20 \mathrm{~cm}$ of the Cassiar Cannery mudflat. All potentially toxic elements studied at the Cassiar Cannery mudflat can be classified as unpolluted due to their low concentration (Muller 1969). This result indicates that if contaminants were present, sediment inputs from the Skeena and Nass River have buried contaminated sediment as part of the passive reclamation process. research is required to see if thresholds exist to the efficacy of passive reclamation and whether these thresholds shift based on the level of disturbance to an estuarine system. Regardless, if thresholds do exist for passive reclamation but the goal is full reclamation, allowing for passive reclamation to the existing threshold before commencing active reclamation may be more cost-effective than a complete active reclamation scheme. 
Overall the Cassiar Cannery mudflat appears to be relatively healthy and reasonably unstressed, and it appears that passive reclamation from historical disturbances has occurred at these locations.

427 Therefore, passive restoration may be an appropriate reclamation technique in other soft-sediment or 428 estuarine ecosystems degraded by industrial activities. However, within the mudflat, some patches 429 (1m2 quadrat) reveal the legacy of past disturbances in the form of patchy distributions of taxa which 430 are known indicators of disturbance. Therefore, thresholds may exist to the efficacy of passive 431 reclamation, and future research should address potential thresholds of reclamation. Regardless, 432 allowing for passive reclamation of the soft-sediment ecosystem to a relatively unstressed state before 433 commencing active reclamation may be successful without the high cost associated with a full active 434 reclamation scheme.

\section{Acknowledgments}

This project was funded by an NSERC CGS M to LC, an NSERC Discovery award and Liber

Ero funds to FJ, a Mitacs Elevate postdoctoral fellowship to TGG, and support to TS from the Royal

Geographical Society (with IBG) in the form of an Environment and Sustainability Research Grant.

440 Without the support of Justine and Mark Crawford of Cassiar Cannery this project would have been

441 impossible, and much gratitude is owed to them. Finally, Aleia Wylie's support was crucial to see this 442 project to completion. 


\section{References}

Ahn IY, Kang YC, Choi JW. 1995. The influence of industrial effluents on intertidal benthic communities in Panweol, Kyeonggi Bay (Yellow Sea) on the west-coast of Korea. Marine Pollution Bulletin. 30(3):200-206.

Akenhead S. 1992. A review of the oceanography and marine ecology of Prince Rupert Harbour a propos sewage outfalls. Prepared for the Institute of Ocean Sciences, Sidney BC.

Altieri AH. 2006. Inducible variation in hypoxia tolerance across the intertidal-subtidal distribution of the blue mussel Mytilus edulis. Marine Ecology Progress Series. 325:295300.

Bett B. 1988. Monitoring with meiofauna. Marine Pollution Bulletin. 19(6):293-294.

Bayraktarov E, Saunders MI, Abdullah S, Mills M, Beher J, Possingham HP, Mumby PJ, Lovelock CE. 2016. The cost and feasibility of marine coastal restoration. Ecological Applications. 26(4):1055-1074.

Benayas JMR, Newton AC, Diaz A, Bullock JM. 2009. Enhancement of biodiversity and ecosystem services by ecological restoration: A meta-analysis. Science. 325(5944):11211124.

Beyer DL, Nakatani RE, Staude CP. 1975. Effects of salmon cannery wastes on water-quality and marine organisms. Journal Water Pollution Control Federation. 47(7):1857-1869.

Borja A, Dauer DM, Elliott M, Simenstad CA. 2010. Medium- and long-term recovery of estuarine and coastal ecosystems: Patterns, rates and restoration effectiveness. Estuaries and Coasts. 33(6):1249-1260.

Borja A, Muxika H. 2005. Guidelines for the use of AMBI (AZTI's marine biotic index) in the assessment of the benthic ecological quality. Marine Pollution Bulletin. 50(7):787-789.

Burke MJW, Grime JP. 1996. An experimental study of plant community invasibility. Ecology. 77(3):776-790.

Buttermore RE. 1977. Eutrophication of an impounded estuarine lagoon. Marine Pollution Bulletin. 8(1):13-15.

Cardoso PG, Bankovic M, Raffaelli D, Pardal MA. 2007. Polychaete assemblages as indicators of habitat recovery in a temperate estuary under eutrophication. Estuarine Coastal and Shelf Science. 71(1-2):301-308.

Campbell L, Wood L, Allen Gerwing AM, Allen S, Sizmur T, Rogers M, Gray O, Drewes M, Juanes F. 2019. A rapid, non-invasive population assessment technique for marine burrowing macrofauna inhabiting soft sediments. In Press at Estuarine, Coastal, and Shelf Science.

Carr-Harris C, Gottesfeld AS, Moore JW. 2015. Juvenile salmon usage of the Skeena River Estuary. Plos One. 10(3): e0118988.

Chollett I, Bone D. 2007. Efffiects of heavy rainfall on polychaetes: Differential spatial patterns generated by a large-scale disturbance. Journal of Experimental Marine Biology and Ecology. 340(2):113-125.

Conlan KE. 1994. Amphipod crustaceans and environmental disturbance - a review. Journal of Natural History. 28(3):519-554.

Constable AJ, Fairweather PG. 1999. Ecology of estuaries and soft-sediment habitats: Symposium introduction. Australian Journal of Ecology. 24(4):289-290.

Coulthard ME, Hamilton DJ. 2011. Effects of Ilyanassa obsoleta (Say) on the abundance and vertical distribution of Corophium volutator (Pallas) on mudflats of the Upper Bay of Fundy. Journal of Experimental Marine Biology and Ecology. 397(2):161-172.

Cowie PR, Widdicombe S, Austen MC. 2000. Effects of physical disturbance on an estuarine intertidal community: Field and mesocosm results compared. Marine Biology. 136(3):485-495. 
Cox KD, Black MJ, Filip N, Miller MR, Mohns K, Mortimor J, Freitas TR, Greiter Loerzer R, Gerwing TG, Juanes F et al. 2017. Community assessment techniques and the implications for rarefaction and extrapolation with Hill numbers. Ecology and Evolution. 7(24):11213-11226.

Crain CM, Kroeker K, Halpern BS. 2008. Interactive and cumulative effects of multiple human stressors in marine systems. Ecology Letters. 11(12):1304-1315.

Davis B, Mattone C, Sheaves M. 2014. Bottom-up control regulates patterns of fish connectivity and assemblage structure in coastal wetlands. Marine Ecology Progress Series. 500:175186.

Dernie KM, Kaiser MJ, Richardson EA, Warwick RM. 2003. Recovery of soft sediment communities and habitats following physical disturbance. Journal of Experimental Marine Biology and Ecology. 285:415-434.

Dissanayake NG, Frid CLJ, Drylie TP, Caswell BA. 2018. Ecological functioning of mudflats: Global analysis reveals both regional differences and widespread conservation of functioning. Marine Ecology Progress Series. 604:1-20.

Faggetter BA. 2008. Review of the environmental and socioeconomic impacts of marine pollution in the north and central coast regions of British Columbia. Prepared for North Coast-Skeena First Nations Stewardship Society.

Fauchald K, Jumars P. 1979. The diet of worms: A study of polychaete feeding guilds. Oceanography and Marine Biology Annual Review. 17:193-284.

Fonseca MS, Fisher JS, Zieman JC, Thayer GW. 1982. Influence of the seagrass, Zostera marina, on current flow. Estuarine Coastal and Shelf Science. 15(4):351-358.

Gerwing TG, Allen Gerwing AM, Macdonald T, Cox K, Juanes F, Dudas SE. 2017a. Intertidal soft-sediment community does not respond to disturbance as postulated by the intermediate disturbance hypothesis. Journal of Sea Research. 129:22-28.

Gerwing T, Campbell L, Allen Gerwing A, Allen S, Cox K, Rogers M, Gray O, Drewes M, Juanes F. 2018a. Potential impacts of logging on intertidal infaunal communities within the Kitimat River Estuary. Journal of Natural History. 52:2833-2855.

Gerwing TG, Cox K, Allen Gerwing AM, Carr-Harris CN, Dudas SE, Juanes F. 2017b. Depth to the apparent redox potential discontinuity (aRPD) as a parameter of interest in marine benthic habitat models. International Journal of Sediment Research. 33:472-480.

Gerwing TG, Drolet D, Barbeau MA, Hamilton DJ, Allen Gerwing AM. 2015a. Resilience of an intertidal infaunal community to winter stressors. Journal of Sea Research. 97:40-49.

Gerwing TG, Allen Gerwing AM, Drolet D, Barbeau MA, Hamilton DJ. 2015b. Spatiotemporal variation in biotic and abiotic features of eight intertidal mudflats in the Upper Bay of Fundy, Canada. Northeastern Naturalist. 22:1-44.

Gerwing TG, Allen Gerwing AM, Drolet D, Hamilton DJ, Barbeau MA. 2013. Comparison of two methods of measuring the depth of the redox potential discontinuity in intertidal mudflat sediments. Marine Ecology Progress Series. 487:7-13.

Gerwing TG, Allen Gerwing AM, Hamilton DJ, Barbeau MA. 2015c. Apparent redox potential discontinuity (aRPD) depth as a relative measure of sediment oxygen content and habitat quality. International Journal of Sediment Research. 30(1):74-80.

Gerwing TG, Allen Gerwing AM, Macdonald T, Cox K, Juanes F, Dudas SE. 2018b. Assessing the relationship between community dispersion and disturbance in a soft-sediment ecosystem. Marine Ecology-an Evolutionary Perspective. 39(4):9.

Gesteira JLG, Dauvin JC. 2000. Amphipods are good bioindicators of the impact of oil spills on soft-bottom macrobenthic communities. Marine Pollution Bulletin. 40(11):1017-1027.

Gonzalez A, Cardinale BJ, Allington GRH, Byrnes J, Endsley KA, Brown DG, Hooper DU, Isbell F, O'Connor MI, Loreau M. 2016. Estimating local biodiversity change: A critique of papers claiming no net loss of local diversity. Ecology. 97(8):1949-1960. 
Guerra-Garcia J, Garcia-Gomez J. 2004. Polychaete assemblages and sediment pollution in a harbour with two opposing entrances. Helgoland Marine Research. 58(3):183-191.

Hansen JA, Skilleter GA. 1994. Effects of the gastropod Rhinoclavis aspera (Linnaeus, 1758) on microbial biomass and productivity in coral-reef-flat sediments. Australian Journal of Marine and Freshwater Research. 45(4):569-584.

Hargrave BT, Prouse NJ, Phillips GA, Neame PA. 1983. Primary production and respiration in pelagic and benthic communities at 2 intertidal sites in the Upper Bay of Fundy. Canadian Journal of Fisheries and Aquatic Sciences. 40:229-243.

Heilskov AC, Holmer M. 2001. Effects of benthic fauna on organic matter mineralization in fishfarm sediments: Importance of size and abundance. ICES Journal of Marine Science. 58(2):427-434.

Herbert RJH, Crowe TP, Bray S, Sheader M. 2009. Disturbance of intertidal soft sediment assemblages caused by swinging boat moorings. Hydrobiologia. 625:105-116.

Holl KD, Aide TM. 2011. When and where to actively restore ecosystems? Forest Ecology and Management. 261(10):1558-1563.

Hooper DU, Chapin FS, Ewel JJ, Hector A, Inchausti P, Lavorel S, Lawton JH, Lodge DM, Loreau M, Naeem S et al. 2005. Effects of biodiversity on ecosystem functioning: A consensus of current knowledge. Ecological Monographs. 75(1):3-35.

Hoos LM. 1975. The Skeena River Estuary: Status of environmental knowledge to 1975: Report of the Estuary Working Group, Dept. of the Environment, Regional Board Pacific Region. Environment Canada.

Katayama T, Nagao N, Goto M, Yusoff FM, Banerjee S, Sato M, Takahashi K, Furuya K. 2018. Growth characteristics of shade-acclimated marine Chlorella vulgaris under high-celldensity conditions. Journal of Environmental Biology. 39(5):747-753.

Kauffman JB, Beschta RL, Otting N, Lytjen D. 1997. An ecological perspective of riparian and stream restoration in the western united states. Fisheries. 22(5):12-24.

Keats RA, Osher LJ, Neckers HA. 2004. The effect of nitrogen loading on a brackish estuarine faunal community: A stable isotope approach. Estuaries. 27(3):460-471.

Kennish MJ. 2002. Environmental threats and environmental future of estuaries. Environmental Conservation. 29(1):78-107.

Kesaniemi JE, Bostrom C, Knott KE. 2012. New genetic markers reveal population genetic structure at different spatial scales in the opportunistic polychaete Pygospio elegans. Hydrobiologia. 691(1):213-223.

Kristensen E. 2000. Organic matter diagenesis at the oxic/anoxic interface in coastal marine sediments, with emphasis on the role of burrowing animals. Hydrobiologia. 426(1-3):124.

Kritzer JP, DeLucia M, Greene E, Shumway C, Topolski MF, Thomas-Blate J, Chiarella LA, Davy KB, Smith K. 2016. The importance of benthic habitats for coastal fisheries. BioScience. 66(4):274-284.

Light SF, Smith RI. 2007. The Light and Smith manual: Intertidal invertebrates from Central California to Oregon. Carlton JT, editor. Berkeley, Los Angeles, CA, USA: University of California Press.

Marquiegui MA, Aguirrezabalaga F. 2009. Colonization process by macrobenthic infauna after a managed coastal realignment in the Bidasoa Estuary (Bay of Biscay, NE Atlantic). Estuarine Coastal and Shelf Science. 84(4):598-604.

McCrackin ML, Jones HP, Jones PC, Moreno-Mateos D. 2017. Recovery of lakes and coastal marine ecosystems from eutrophication: A global meta-analysis. Limnology and Oceanography. 62(2):507-518. 
McLaren P. 2016. The environmental implications of sediment transport in the waters of Prince Rupert, British Columbia, Canada: A comparison between kinematic and dynamic approaches. Journal of Coastal Research. 32(3):465-482.

Muller G. 1969. Index of geoaccumulation in sediments of the Rhine River. Geojournal. 2:108118.

Muller C, Reuter W, Wehrmeyer W, Dau H, Senger H. 1993. Adaptation of the photosynthetic apparatus of Anacystis nidulans to irradiance and $\mathrm{CO}_{2}$-concentration. Botanica Acta. 106(6):480-487.

Ozdemir A, Duran M, Sen A. 2011. Potential use of the oligochaete Limnodrilus profundicola v., as a bioindicator of contaminant exposure. Environmental Toxicology. 26(1):37-44.

Page DS, Boehm PD, Douglas GS, Bence AE, Burns WA, Mankiewicz PJ. 1999. Pyrogenic polycyclic aromatic hydrocarbons in sediments record past human activity: A case study in Prince William Sound, Alaska. Marine Pollution Bulletin. 38(4):247-260.

Pearson T, Rosenberg R. 1976. A comparative study of the effects on the marine environment of wastes from cellulose. Ambio. 5(2):77-79.

Pearson TH, Rosenberg R. 1978. Macrobenthic succession in relation to organic enrichment and pollution of the marine environment. Oceanography and Marine Biology: An Annual Review. 16:229-331.

Pearson TH, Stanley SO. 1979. Comparative measurement of the redox potential of marinesediments as a rapid means of assessing the effect of organic pollution. Marine Biology. 53(4):371-379.

Pinto R, Patrício J, Baeta A, Fath BD, Neto JM, Marques JC. 2009. Review and evaluation of estuarine biotic indices to assess benthic condition. Ecological Indicators. 9(1):1-25.

Pires A, Velez C, Figueira E, Soares A, Freitas R. 2017. Effects of sediment contamination on physiological and biochemical responses of the polychaete Diopatra neapolitana, an exploited natural resource. Marine Pollution Bulletin. 119(1):119-131.

Pocklington P, Wells PG. 1992. Polychaetes - key taxa for marine environmental-quality monitoring. Marine Pollution Bulletin. 24(12):593-598.

Raps S, Wyman K, Siegelman HW, Falkowski PG. 1983. Adaptation of the cyanobacterium Microcystis aeruginosa to light-intensity. Plant Physiology. 72(3):829-832.

Schlacher TA, Lucrezi S, Peterson CH, Connolly RM, Olds AD, Althaus F, Hyndes GA, Maslo B, Gilby BL, Leon JX et al. 2016. Estimating animal populations and body sizes from burrows: Marine ecologists have their heads buried in the sand. Journal of Sea Research. 112:55-64.

Schlacher TA, Thompson L. 2013. Spatial structure on ocean-exposed sandy beaches: Faunal zonation metrics and their variability. Marine Ecology Progress Series. 478:43-55.

Skilleter GA. 1996. An experimental test of artifacts from repeated sampling in soft-sediments. Journal of Experimental Marine Biology and Ecology. 205(1-2):137-148.

Simenstad C, Reed D, Ford C. 2006. When is restoration not? Incorporating landscape-scale processes to restore self-sustaining ecosystems in coastal wetland restoration. Ecological Engineering. 26:27-39.

Sizmur T, Campbell L, Dracott K, Jones M, O’Driscoll NJ, Gerwing T. 2019. Survey of intertidal ecosystem reveals a lecacy of potentially toxic elements from industrial activity in the Skeena Estuary, British Columbia, Canada. In Press at Estuaries and Coasts.

Smith MD, Knapp AK. 1999. Exotic plant species in a C-4-dominated grassland: Invasibility, disturbance, and community structure. Oecologia. 120(4):605-612.

Stone FE, Barnett HJ, Hunter PJ, Roberts GC, Nelson RW. 1981. Processing waste-water from 2 mechanized salmon canneries. Marine Fisheries Review. 43(1):21-25.

Szabo P. 2010. Why history matters in ecology: An interdisciplinary perspective. Environmental Conservation. 37(4):380-387. 
Thomas JD. 1993. Biological monitoring and tropical biodiversity in marine environments - a critique with recommendations, and comments on the use of amphipods as bioindicators. Journal of Natural History. 27(4):795-806.

Thrush SF, Hewitt JE, Norkko A, Cummings VJ, Funnell GA. 2003. Macrobenthic recovery processes following catastrophic sedimentation on estuarine sandflats. Ecological Applications. 13(5):1433-1455.

Trites M, Kaczmarska I, Ehrman JM, Hicklin PW, Ollerhead J. 2005. Diatoms from two macrotidal mudflats in Chignecto Bay, Upper Bay of Fundy, New Brunswick, Canada. Hydrobiologia. 544:299-319.

Turner A. 2019. Lead pollution of coastal sediments by ceramic waste. Marine Pollution Bulletin. 138:171-176.

Underwood AJ. 1997. Experiments in ecology: Their logical design and interpretation using analysis of variance. New York, NY: Cambridge University Press.

Underwood AJ. 1994. On beyond BACI - sampling designs that might reliably detect environmental disturbances. Ecological Applications. 4(1):3-15.

Underwood AJ. 2009. Components of design in ecological field experiments. Annales Zoologici Fennici. 46(2):93-111.

Vackar D, ten Brink B, Loh J, Baillie JEM, Reyers B. 2012. Review of multispecies indices for monitoring human impacts on biodiversity. Ecological Indicators. 17:58-67.

Valdivia N, Scrosati RA, Molis M, Knox AS. 2011. Variation in community structure across vertical intertidal stress gradients: How does it compare with horizontal variation at different scales? Plos One. 6(8):8.

Veloso VG, Neves G, Lozano M, Perez-Hurtado A, Gago CG, Hortas F, Garcia FG. 2008. Responses of Talitrid amphipods to a gradient of recreational pressure caused by beach urbanization. Marine Ecology-an Evolutionary Perspective. 29:126-133.

Waldichuk M. 1966. Effects of sulfite wastes in a partially enclosed marine system in British Columbia. Journal Water Pollution Control Federation. 38(9):1484-1505.

Waldichuk M. 1979. Ecological impact of logs. Marine Pollution Bulletin. 10(2):33-34.

Wilkes B, Dwernychuk L. 1991. Environment studies in the marine receiving environment at the Skeena cellulose pulp mill, Watson Island, BC. Pulp \& Paper Canada. 92(10):20-27.

Wu RSS. 1995. The environmental impact of marine fish culture: Towards a sustainable future. Marine Pollution Bulletin. 31(4-12):159-166.

Yunker MB, Cretney WJ, Ikonomou MG. 2002. Assessment of chlorinated dibenzo-p-dioxin and dibenzofuran trends in sediment and crab hepatopancreas from pulp mill and harbor sites using multivariate and index-based approaches. Environmental Science \& Technology. 36(9):1869-1878. 


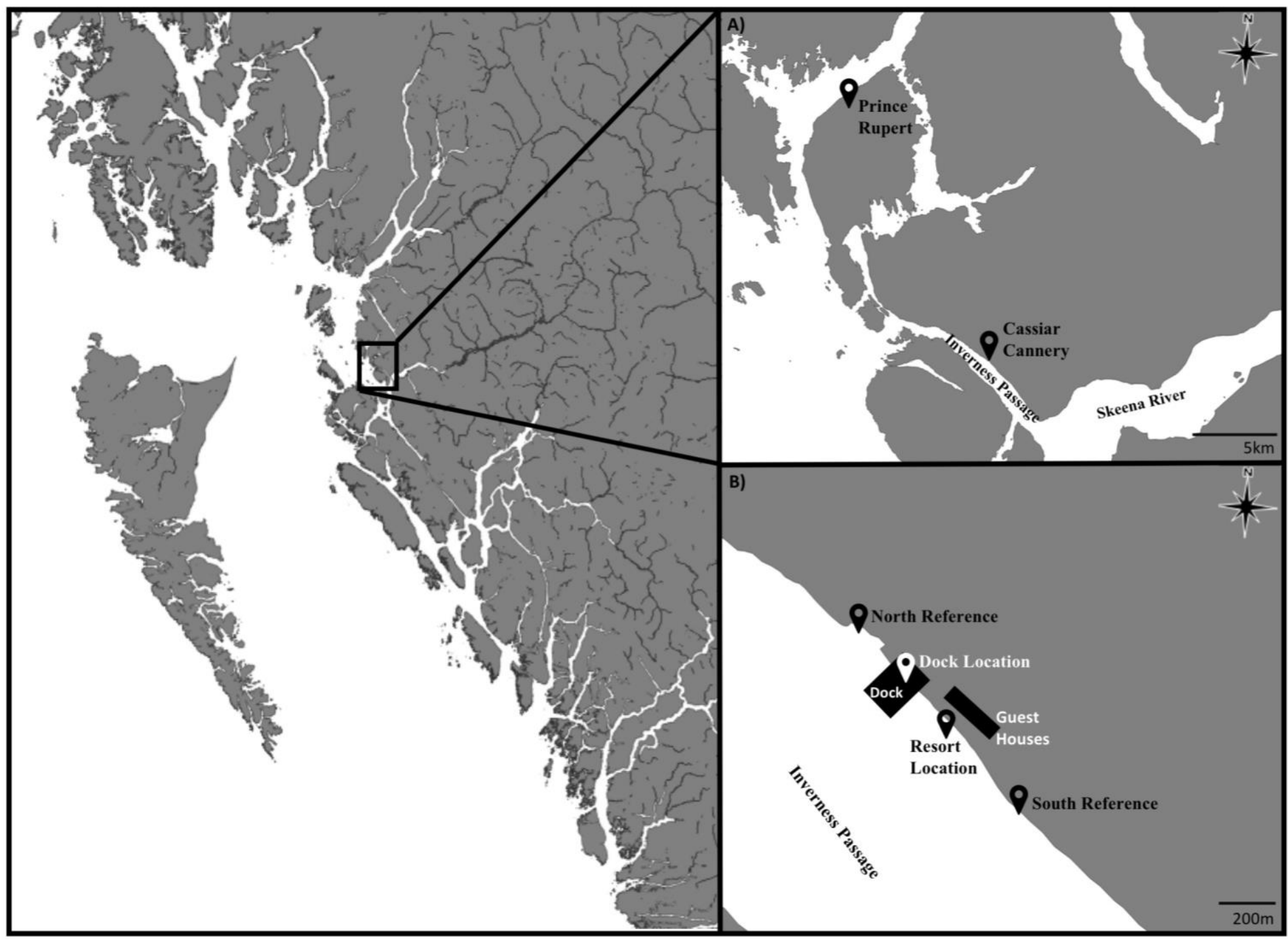

Figure 1. Location of the Cassiar Cannery mudflat $\left(54.178092^{\circ},-130.176924^{\circ}\right)$ sampled during summer 2017 , in Inverness Passage, British Columbia, Canada. A) shows the location of the Cassiar Cannery mudflat within Inverness Passage relative to the Skeena River and Prince Rupert. B) shows the 4 locations sampled on the Cassiar Cannery mudflat. DL: Dock Location (benthos underneath the dock denoted by DK), RL: Resort Location (in front of guest houses denoted by GH), NR: North Reference, SR: South Reference. 
A)

\section{Location}

$\boldsymbol{\Delta} \mathrm{DL}$

$\nabla$

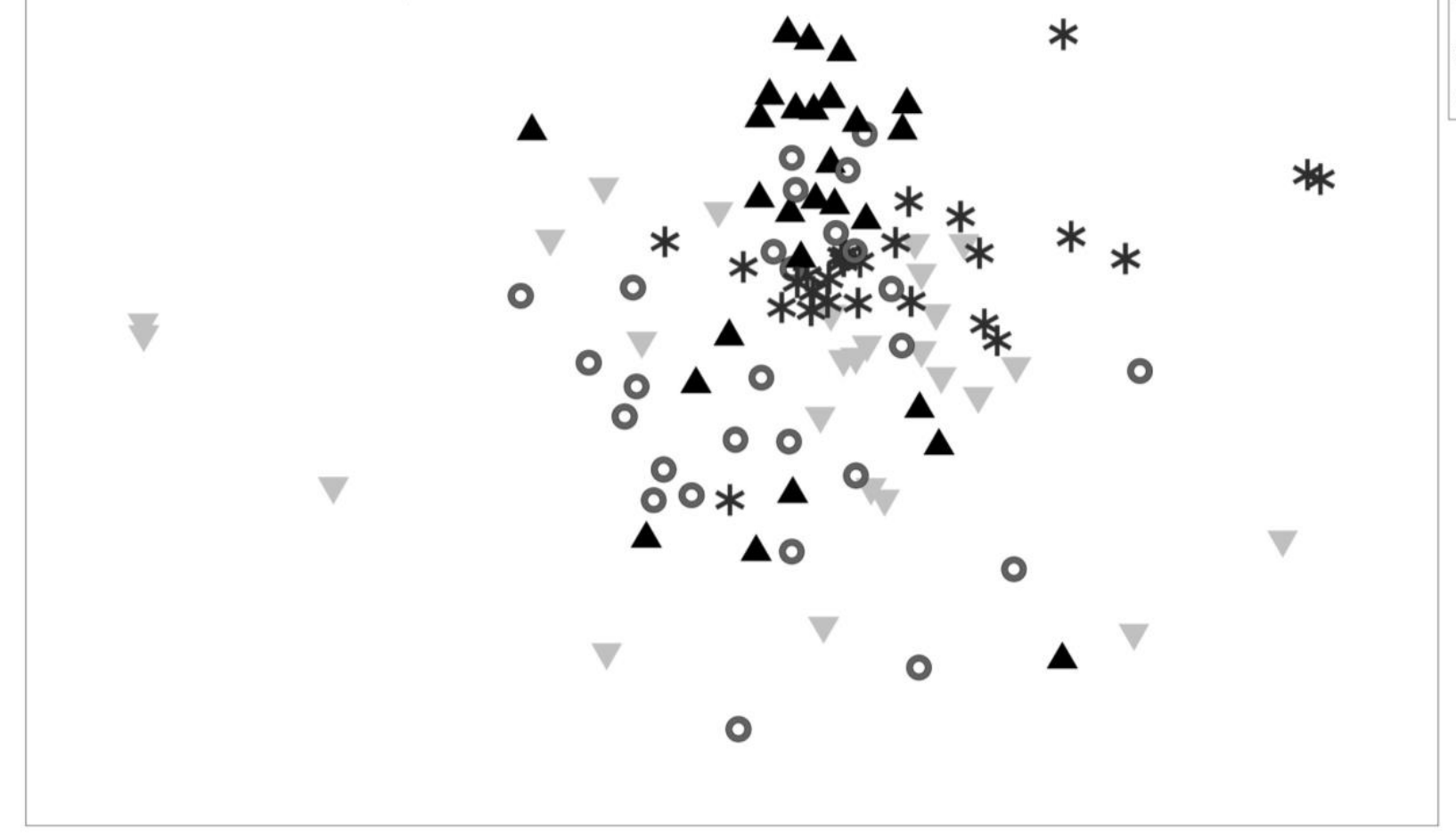

B)

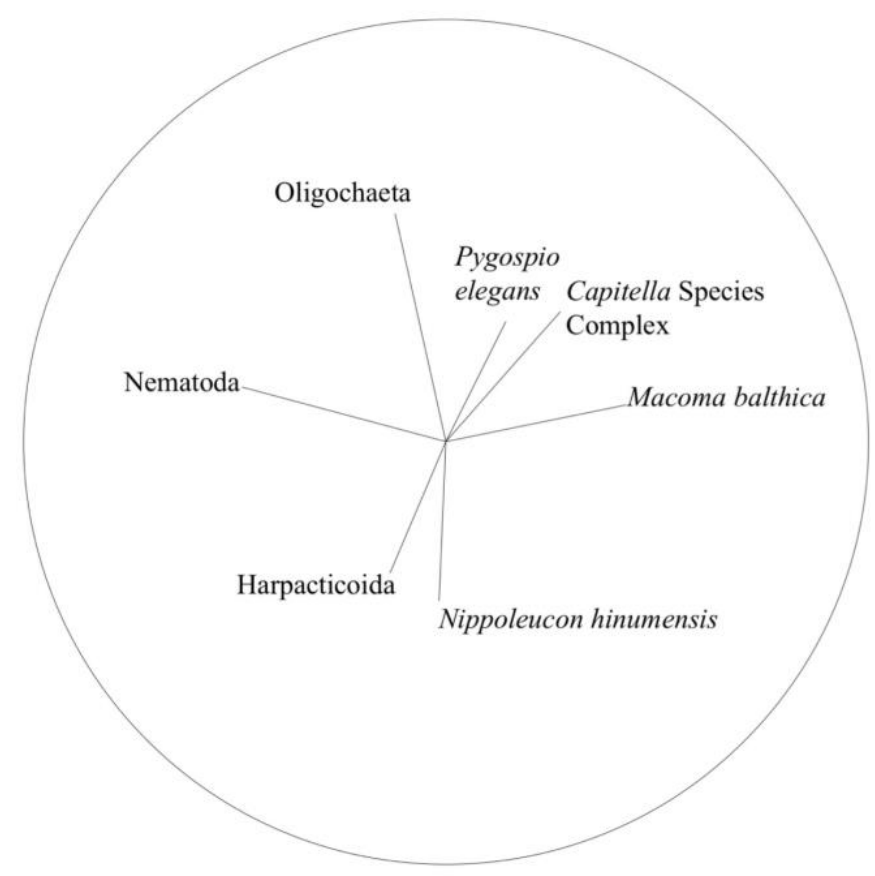

Figure 2. Non-metric multidimensional scaling (nMDS) graphs showing infaunal invertebrate community at four locations on the intertidal mudflat at Cassiar Cannery in Inverness Passage, British Columbia, during the summer of 2017. A) the infaunal community by location and B) the vector overlay indicates the direction of increased density, with correlations > 0.3 shown. DL: Dock Location. RL: Resort Location. NR: North Reference. SR: South Reference. 
A)

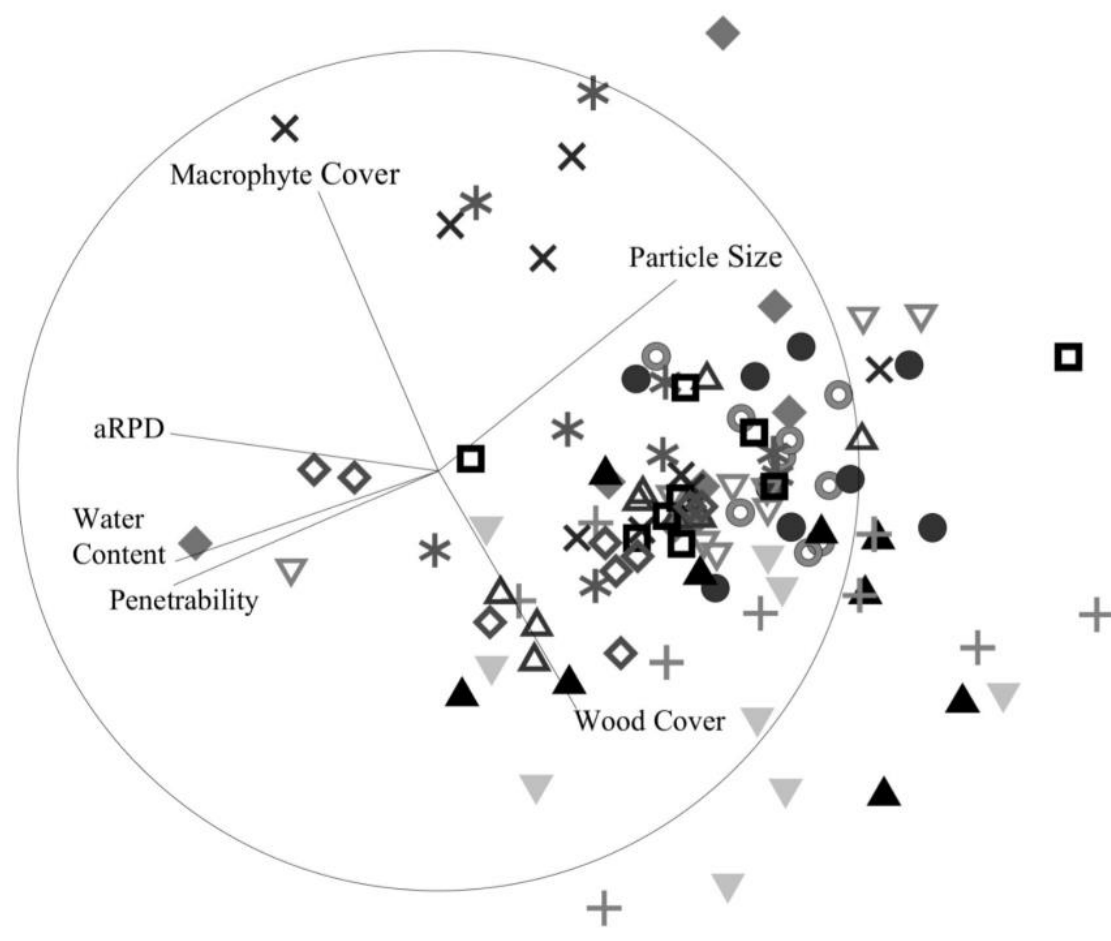

A May 30; DL

June 21; DL

+ July 20; DL

- May $30 ; \mathrm{RL}$

June 21; RL

July 20; RL

X May 30 ; NR

* June 21; NR

$\Delta$ July $20 ;$ NR

$\nabla$ May 30; SR

- June 21; SR

$\diamond$ July 20 ; SR

B)

2D Stress: 0
Date

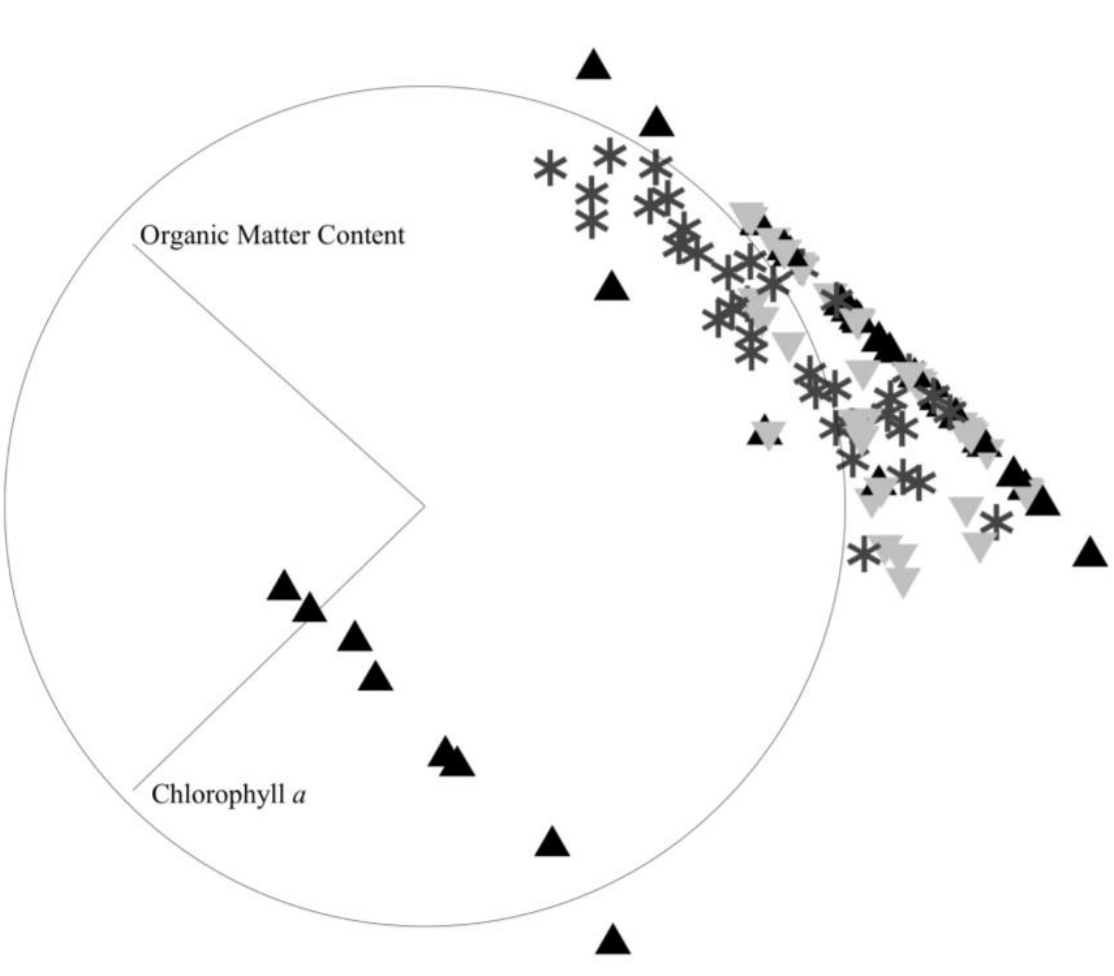

Figure 3. Non-metric multidimensional scaling (nMDS) graphs of A) sediment parameters (depth to the aRPD, water content, particle size, penetrability, \% macroalgae coverage, and \% wood cover) by time and location and B) the nutrient availability (chlorophyll $a$ and organic matter content) at four locations on the intertidal mudflat at Cassiar Cannery in Inverness Passage, British Columbia, during the summer of 2017. Vector overlays for sediment and nutrient variables show the correlation between variables and nMDS axes, with each vector showing the direction of increased value. DL: Dock Location. RL: Resort Location. NR: North Reference. SR: South Reference. 
Table 1. Permutational multivariate analysis of variance (PERMANOVA) quantifying the spatiotemporal variation in A) infaunal invertebrate community, and B) taxonomic richness, and C) sediment parameters, and D) the nutrient parameters at four locations at the intertidal mudflat at Cassiar Cannery during the summer of 2017. DL: Dock Location. RL: Resort Location. NR: North Reference. SR: South Reference. Significant p values $(\alpha<0.05)$ are denoted in bold.

\begin{tabular}{|c|c|c|c|c|c|}
\hline \multicolumn{6}{|l|}{ A) } \\
\hline Source & $\mathrm{df}$ & MS & Pseudo-F & $\begin{array}{c}\text { Unique } \\
\text { Permutations }\end{array}$ & $\mathrm{p}$ \\
\hline Date & 2 & 6939.90 & 6.93 & 4982 & 0.0002 \\
\hline Location & 3 & 6316.20 & 3.38 & 4237 & 0.0002 \\
\hline DL vs $(\mathbf{N R}+\mathbf{S R})$ & 1 & 6973.10 & 6.95 & 4986 & 0.0002 \\
\hline RL vs (NR + SR) & 1 & 5798.70 & 4.69 & 4992 & 0.0008 \\
\hline DL vs RL & 1 & 7738.00 & 5.97 & 4990 & 0.0002 \\
\hline NR vs SR & 1 & 5500.80 & 5.81 & 4986 & 0.0002 \\
\hline Transect(Location) & 8 & 1869.20 & 2.11 & 4971 & 0.0002 \\
\hline Date X Location & 6 & 1345.20 & 1.34 & 4978 & 0.1550 \\
\hline Date X Transect(Location) & 16 & 1001.50 & 1.13 & 4958 & 0.2372 \\
\hline Residual & 72 & 885.96 & & & \\
\hline Total & 107 & & & & \\
\hline \multicolumn{6}{|l|}{ B) } \\
\hline Source & $\mathrm{df}$ & MS & Pseudo-F & $\begin{array}{c}\text { Unique } \\
\text { Permutations }\end{array}$ & $\mathrm{p}$ \\
\hline Date & 2 & 435.28 & 2.13 & 4990 & 0.0950 \\
\hline Location & 3 & 1004.20 & 0.90 & 4225 & 0.5298 \\
\hline Transect(Location) & 8 & 1121.80 & 4.57 & 4975 & 0.0002 \\
\hline Date X Location & 6 & 244.31 & 1.19 & 4988 & 0.3290 \\
\hline Date X Transect(Location) & 16 & 204.67 & 0.83 & 4978 & 0.6982 \\
\hline Residual & 72 & 245.43 & & & \\
\hline Total & 107 & & & & \\
\hline \multicolumn{6}{|l|}{ C) } \\
\hline Source & $\mathrm{df}$ & MS & Pseudo-F & $\begin{array}{c}\text { Unique } \\
\text { Permutations }\end{array}$ & $\mathrm{p}$ \\
\hline Date & 2 & 4.58 & 1.29 & 4974 & 0.2670 \\
\hline Location & 3 & 35.72 & 5.48 & 4248 & 0.0004 \\
\hline Transect(Location) & 8 & 6.52 & 1.25 & 4977 & 0.1486 \\
\hline Date X Location & 6 & 6.96 & 1.96 & 4982 & 0.0278 \\
\hline Date X Transect(Location) & 16 & 3.55 & 0.68 & 4961 & 0.9826 \\
\hline Residual & 72 & 5.21 & & & \\
\hline Total & 107 & & & & \\
\hline \multicolumn{6}{|l|}{ D) } \\
\hline Source & $\mathrm{df}$ & MS & Pseudo-F & $\begin{array}{c}\text { Unique } \\
\text { permutations }\end{array}$ & $\mathrm{p}$ \\
\hline Date & 2 & 9.76 & 11.49 & 4989 & 0.0002 \\
\hline May 30 vs June 21 & 1 & 7.74 & 8.79 & 4987 & 0.0002 \\
\hline May 30 vs July 20 & 1 & 6.77 & 3.50 & 4987 & 0.0306 \\
\hline June 21 vs July 20 & 1 & 15.85 & 8.79 & 4987 & 0.0002 \\
\hline Location & 3 & 2.35 & 1.12 & 4258 & 0.4162 \\
\hline Transect(Location) & 8 & 2.10 & 0.99 & 4983 & 0.4696 \\
\hline Date X Location & 6 & 0.69 & 0.81 & 4980 & 0.6526 \\
\hline Date X Transect(Location) & 16 & 0.85 & 0.40 & 4967 & 0.9976 \\
\hline Residual & 72 & 2.12 & & & \\
\hline Total & 107 & & & & \\
\hline
\end{tabular}


Table 2. Permutational multivariate analysis of variance (PERMANOVA) quantifying the spatiotemporal variation in sediment variables on three sampling dates at the Cassiar Cannery intertidal mudflat during the summer of 2017. Date was run as separate PERMANOVAs due to the significant interaction term between Date X Location in Table 1. DL: Dock Location. RL: Resort Location. NR: North Reference. SR: South Reference. Significant $\mathrm{p}$ values $(\alpha<0.05)$ are denoted in bold.

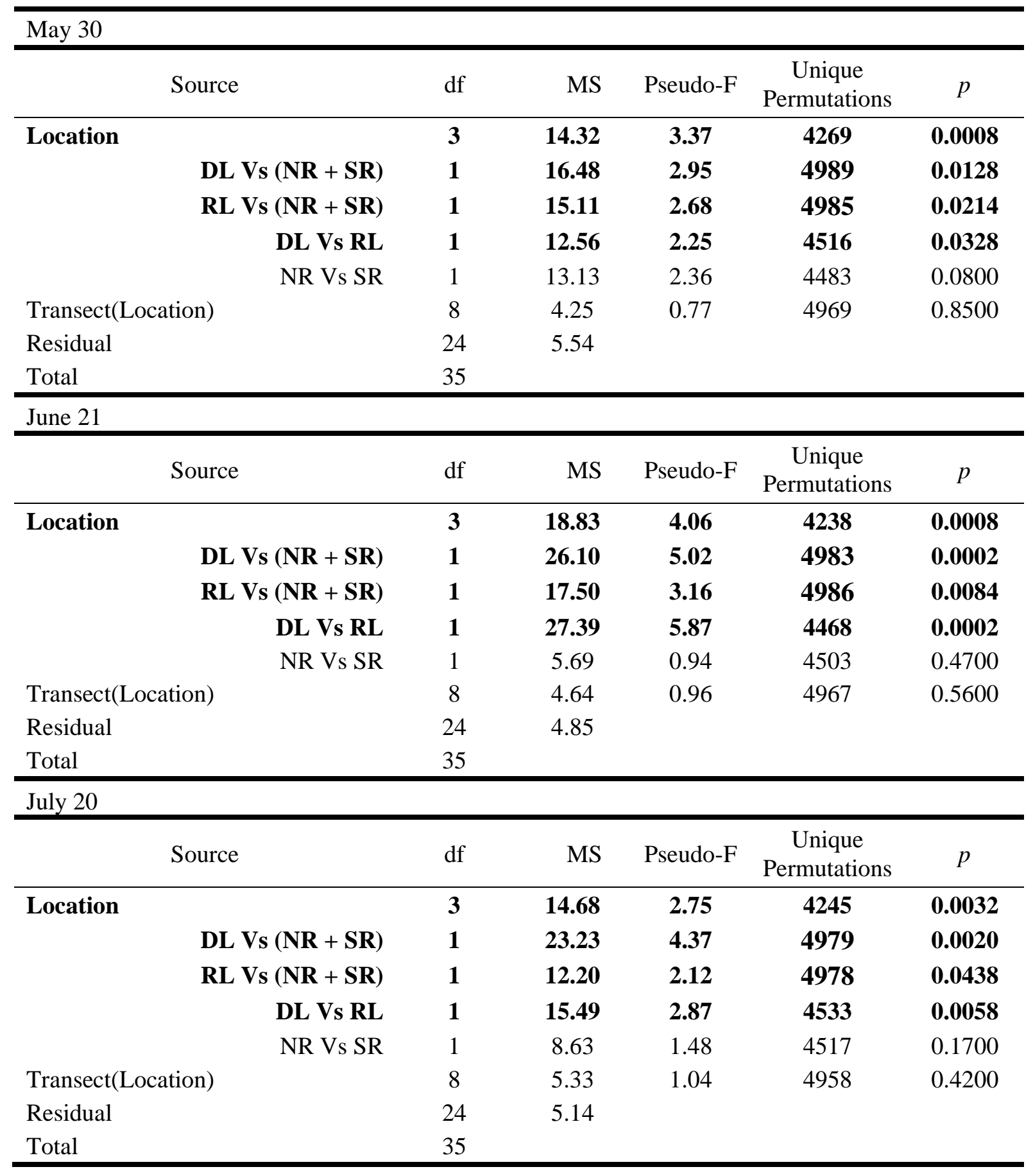


Table 3. SIMPER (Similarity Percentages) determining the contribution of each taxonomic grouping to the observed differences between intertidal locations at Cassiar Cannery in Inverness Passage during summer of 2017. Diss/SD represents the ratio of the dissimilarity to the standard deviation. Values $>1$, denoted in bold, represent groups that consistently contribute to the observed differences between location types. Taxa with Diss/SD $<1$ did not consistently contribute to the observed differences between location types. Only groups that contributed $\geq 1 \%$ to the observed differences between locations are shown. DL: Dock Location. RL: Resort Location. NR: North Reference. SR: South Reference.

\begin{tabular}{|c|c|c|c|c|c|c|c|c|c|c|c|c|c|}
\hline DL vs (NR+SR) & & & & & & & RL vs (NR+SR) & & & & & & \\
\hline Average Dissimilarity $=45.90 \%$ & DL & $(\mathrm{NR}+\mathrm{SR})$ & & & & & Average Dissimilarity $=50.09 \%$ & RL & $(\mathrm{NR}+\mathrm{SR})$ & & & & \\
\hline Species & Abundance & Abundance & Av.Diss & Diss/SD & $\begin{array}{c}\text { Contribution } \\
(\%) \\
\end{array}$ & $\begin{array}{c}\text { Cumulative } \\
(\%)\end{array}$ & Species & Abundance & Abundance & Av.Diss & Diss/SD & $\begin{array}{c}\begin{array}{c}\text { Contribution } \\
(\%)\end{array} \\
\end{array}$ & $\begin{array}{c}\text { Cumulative } \\
\text { (\%) }\end{array}$ \\
\hline Oligochaeta & 5.55 & 3.23 & 5.01 & 1.23 & 10.91 & 10.91 & Capitella Species Complex & 3.71 & 5.49 & 5.95 & 1.18 & 11.88 & 11.88 \\
\hline Pygospio elegans & 6.08 & 4.71 & 4.85 & 1.19 & 10.56 & 21.47 & Nematoda & 4.74 & 6.10 & 5.87 & 1.18 & 11.72 & 23.59 \\
\hline Nematoda & 7.00 & 6.10 & 4.55 & 1.13 & 9.91 & 31.38 & Pygospio elegans & 4.57 & 4.71 & 5.41 & 1.20 & 10.80 & 34.39 \\
\hline Harpacticoida & 1.06 & 4.03 & 4.38 & 1.24 & 9.54 & 40.93 & Americorophium salmonis & 4.82 & 4.76 & 5.00 & 1.14 & 9.98 & 44.37 \\
\hline Americorophium salmonis & 2.66 & 4.76 & 4.23 & 1.27 & 9.22 & 50.15 & Macoma balthica & 3.60 & 4.68 & 4.54 & 0.98 & 9.06 & 53.43 \\
\hline Capitella Species Complex & 3.70 & 5.49 & 4.15 & 1.20 & 9.05 & 59.19 & Eteone californica & 2.90 & 4.07 & 4.21 & 1.09 & 8.40 & 61.82 \\
\hline Nippoleucon hinumensis & 2.79 & 2.27 & 3.61 & 1.05 & 7.86 & 67.05 & Oligochaeta & 1.07 & 3.23 & 4.16 & 1.08 & 8.30 & 70.13 \\
\hline Eteone californica & 2.49 & 4.07 & 3.35 & 1.12 & 7.30 & 74.35 & Harpacticoida & 3.37 & 4.03 & 4.12 & 0.96 & 8.22 & 78.35 \\
\hline Aricidea hartleyi & 2.29 & 0.07 & 2.55 & 0.79 & 5.56 & 79.91 & Nippoleucon hinumensis & 1.76 & 2.27 & 3.56 & 0.94 & 7.11 & 85.45 \\
\hline Macoma balthica & 4.99 & 4.68 & 2.45 & 0.94 & 5.34 & 85.26 & Cumella vulgaris & 1.13 & 0.45 & 1.90 & 0.62 & 3.79 & 89.25 \\
\hline Cumella vulgaris & 1.67 & 0.45 & 2.13 & 0.78 & 4.64 & 89.90 & Chironomidae Larvae & 0.99 & 0.00 & 1.34 & 0.49 & 2.68 & 91.93 \\
\hline Paranemertes peregrina & 0.66 & 0.81 & 1.38 & 0.61 & 3.00 & 92.90 & Paranemertes peregrina & 0.18 & 0.81 & 1.12 & 0.49 & 2.24 & 94.17 \\
\hline Abarenicola pacifica & 0.18 & 0.85 & 1.06 & 0.48 & 2.31 & 95.21 & Abarenicola pacifica & 0.00 & 0.85 & 1.07 & 0.43 & 2.14 & 96.31 \\
\hline Ostracoda & 0.30 & 0.32 & 0.76 & 0.39 & 1.66 & 96.87 & Ostracoda & 0.15 & 0.32 & 0.67 & 0.32 & 1.35 & 97.65 \\
\hline Fabricia stellaris & 0.41 & 0.13 & 0.51 & 0.31 & 1.10 & 97.97 & & & & & & & \\
\hline DL vs RL & & & & & & & NR vs SR & & & & & & \\
\hline Average Dissimilarity $=52.98 \%$ & DL & RL & & & & & Average Dissimilarity $=44.17 \%$ & NR & SR & & & & \\
\hline Species & Abundance & Abundance & Av.Diss & Diss/SD & $\begin{array}{c}\text { Contribution } \\
(\%)\end{array}$ & $\begin{array}{l}\text { Cumulative } \\
\text { (\%) }\end{array}$ & Species & Abundance & Abundance & Av.Diss & Diss/SD & $\begin{array}{c}\text { Contribution } \\
(\%)\end{array}$ & $\begin{array}{c}\text { Cumulative } \\
\text { (\%) }\end{array}$ \\
\hline Oligochaeta & 5.55 & 1.07 & 6.81 & 1.37 & 12.86 & 12.86 & Nematoda & 5.11 & 7.09 & 5.81 & 1.14 & 13.15 & 13.15 \\
\hline Pygospio elegans & 6.08 & 4.57 & 5.42 & 1.14 & 10.22 & 23.08 & Pygospio elegans & 6.29 & 3.13 & 5.62 & 1.40 & 12.72 & 25.86 \\
\hline Capitella Species Complex & 3.70 & 3.71 & 4.93 & 1.21 & 9.30 & 32.39 & Capitella Species Complex & 6.82 & 4.15 & 4.65 & 1.33 & 10.53 & 36.39 \\
\hline Americorophium salmonis & 2.66 & 4.82 & 4.82 & 1.24 & 9.10 & 41.48 & Americorophium salmonis & 5.92 & 3.60 & 4.57 & 1.26 & 10.35 & 46.74 \\
\hline Nematoda & 7.00 & 4.74 & 4.80 & 1.26 & 9.06 & 50.54 & Harpacticoida & 3.81 & 4.24 & 3.89 & 1.00 & 8.81 & 55.56 \\
\hline Macoma balthica & 4.99 & 3.60 & 4.40 & 1.01 & 8.31 & $\mathbf{5 8 . 8 5}$ & Oligochaeta & 3.56 & 2.90 & 3.82 & 1.19 & 8.64 & 64.20 \\
\hline Harpacticoida & 1.06 & 3.37 & 4.16 & 1.23 & 7.84 & 66.69 & Nippoleucon hinumensis & 1.81 & 2.74 & 3.54 & 1.02 & 8.01 & 72.21 \\
\hline Nippoleucon hinumensis & 2.79 & 1.76 & 4.02 & 0.95 & 7.59 & 74.28 & Eteone californica & 3.75 & 4.40 & 2.98 & 0.95 & 6.75 & 78.96 \\
\hline Eteone californica & 2.49 & 2.90 & 3.75 & 1.08 & 7.08 & 81.36 & Macoma balthica & 5.33 & 4.03 & 2.76 & 1.06 & 6.24 & 85.20 \\
\hline Aricidea hartleyi & 2.29 & 0.00 & 2.85 & 0.77 & 5.39 & 86.75 & Abarenicola pacifica & 1.15 & 0.55 & 1.68 & 0.63 & 3.81 & 89.02 \\
\hline Cumella vulgaris & 1.67 & 1.13 & 2.69 & 0.86 & 5.08 & 91.83 & Paranemertes peregrina & 1.27 & 0.34 & 1.62 & 0.68 & 3.68 & 92.69 \\
\hline Chironomidae Larvae & 0.33 & 0.99 & 1.66 & 0.55 & 3.14 & 94.97 & Cumella vulgaris & 0.15 & 0.76 & 1.03 & 0.43 & 2.32 & 95.02 \\
\hline Paranemertes peregrina & 0.66 & 0.18 & 0.94 & 0.45 & 1.77 & 96.74 & Ostracoda & 0.00 & 0.64 & 0.82 & 0.39 & 1.85 & 96.87 \\
\hline Ostracoda & 0.30 & 0.15 & 0.66 & 0.33 & 1.24 & 97.98 & Eogammarus confervicolus & 0.49 & 0.00 & 0.58 & 0.34 & 1.31 & 98.18 \\
\hline
\end{tabular}


Table 4. SIMPER (Similarity Percentages) showing percent contribution (\%) of each sediment variable collected at each quadrat (normalized) to the dissimilarity in sediment environment at Cassiar Cannery in Inverness Passage, during 2017. Particle size, aRPD, wood cover, and macrophyte cover were SQRT(X) transformed. Av. Sq. Dist: Average squared distance. Sq Dis/SD: Ratio of the average squared distance to the standard deviation. Values $>1$, denoted in bold, represent variables that consistently contribute to the observed differences between location types. DL: Dock Location. RL: Resort Location. NR: North Reference. SR: South Reference.

\begin{tabular}{|c|c|c|c|c|c|c|c|c|c|c|c|c|c|c|}
\hline \multicolumn{5}{|c|}{$\begin{array}{l}\text { May 30; DL vs (NR + SR) } \\
\text { Average Squared Distance = } 12.92\end{array}$} & \multicolumn{5}{|c|}{$\begin{array}{l}\text { May 30; RL vs (NR + SR) } \\
\text { Average Squared Distance=12.29 }\end{array}$} & \multicolumn{5}{|c|}{$\begin{array}{l}\text { May 30; DL vs RL } \\
\text { Average Squared Distance = } 12.73\end{array}$} \\
\hline Variable & Av.Sq.Dist & Sq.Dist/SD & $\begin{array}{l}\text { Contribution } \\
(\%)\end{array}$ & $\begin{array}{l}\text { Cumulative } \\
\text { (\%) }\end{array}$ & Variable & Av.Sq.Dist & Sq.Dist/SD & $\begin{array}{c}\text { Contribution } \\
(\%)\end{array}$ & $\begin{array}{c}\text { Cumulative } \\
\text { (\%) }\end{array}$ & Variable & Av.Sq.Dist & Sq.Dist/SD & $\begin{array}{l}\text { Contribution } \\
\text { (\%) }\end{array}$ & $\begin{array}{l}\text { Cumulative } \\
\text { (\%) }\end{array}$ \\
\hline Wood Cover (\%) & 3.48 & 0.74 & 26.94 & 26.94 & Wood Cover (\%) & 2.74 & 0.57 & 22.28 & 22.28 & Wood Cover (\%) & 2.40 & 0.71 & 18.87 & 18.87 \\
\hline Penetrability (mm) & 2.34 & 0.81 & 18.08 & 45.02 & Penetrability (mm) & 2.17 & 0.79 & 17.67 & 39.94 & Penetrability (mm) & 2.25 & 0.74 & 17.69 & 36.56 \\
\hline aRPD (mm) & 1.98 & 0.53 & 15.30 & 60.32 & Water Content (\%) & 2.06 & 0.60 & 16.73 & 56.68 & Macrophyte Cover (\%) & 2.15 & 0.43 & 16.93 & 53.48 \\
\hline Water Content (\%) & 1.86 & 0.63 & 14.42 & 74.73 & aRPD (mm) & 1.97 & 0.46 & 16.04 & 72.71 & Water Content (\%) & 2.07 & 0.72 & 16.24 & 69.72 \\
\hline Macrophyte Cover (\%) & 1.73 & 0.53 & 13.43 & 88.16 & Particle Size & 1.70 & 0.70 & 13.81 & 86.53 & aRPD (mm) & 1.95 & 0.77 & 15.31 & 85.03 \\
\hline Particle Size & 1.53 & 0.77 & 11.84 & 100 & Macrophyte Cover (\%) & 1.66 & 0.58 & 13.47 & 100 & Particle Size & 1.91 & 0.71 & 14.97 & 100 \\
\hline \multirow{2}{*}{\multicolumn{5}{|c|}{$\begin{array}{l}\text { June 21; DL vs (NR + SR) } \\
\text { Average Squared Distance = } 13.95\end{array}$}} & \multirow{2}{*}{\multicolumn{5}{|c|}{$\begin{array}{l}\text { June 21; RL vs (NR + SR) } \\
\text { Average Squared Distance = } 12.82\end{array}$}} & \multirow{2}{*}{\multicolumn{5}{|c|}{$\begin{array}{l}\text { June 21; DL vs RL } \\
\text { Average Squared Distance=14.38 }\end{array}$}} \\
\hline & & & & & & & & & & & & & & \\
\hline & & & Contribution & Cumulative & & & & Contribution & Cumulative & & & & Contribution & Cumulative \\
\hline Variable & Av.Sq.Dist & Sq.Dist/SD & (\%) & (\%) & Variable & Av.Sq.Dist & Sq.Dist/SD & (\%) & (\%) & Variable & Av.Sq.Dist & Sq.Dist/SD & (\%) & (\%) \\
\hline Wood Cover (\%) & 3.78 & 1.18 & 27.09 & 27.09 & aRPD (mm) & 2.61 & 0.79 & 20.35 & 20.35 & Wood Cover (\%) & 2.92 & 1.09 & 20.28 & 20.28 \\
\hline Penetrability (mm) & 2.53 & 0.80 & 18.12 & 45.21 & Penetrability (mm) & 2.34 & 0.76 & 18.28 & 38.62 & Penetrability (mm) & 2.72 & 0.9 & 18.92 & 39.2 \\
\hline Water Content (\%) & 2.08 & 0.87 & 14.92 & 60.13 & Wood Cover (\%) & 2.27 & 0.76 & 17.71 & 56.33 & aRPD (mm) & 2.32 & 0.59 & 16.11 & 55.31 \\
\hline $\operatorname{aRPD}(\mathrm{mm})$ & 2.03 & 0.77 & 14.56 & 74.69 & Particle Size & 2.06 & 0.63 & 16.05 & 72.39 & Water Content (\%) & 2.27 & 0.87 & 15.76 & 71.07 \\
\hline Particle Size & 1.81 & 0.49 & 12.94 & 87.63 & Water Content (\%) & 1.87 & 0.70 & 14.59 & 86.97 & Macrophyte Cover (\%) & 2.24 & 0.63 & 15.61 & 86.67 \\
\hline Macrophyte Cover (\%) & 1.73 & 0.44 & 12.37 & 100 & Macrophyte Cover (\%) & 1.67 & 0.53 & 13.03 & 100 & Particle Size & 1.92 & 0.68 & 13.33 & 100 \\
\hline \multirow{2}{*}{\multicolumn{5}{|c|}{$\begin{array}{l}\text { July 20; DL vs (NR + SR) } \\
\text { Average Squared Distance = } 14.12\end{array}$}} & \multirow{2}{*}{\multicolumn{5}{|c|}{$\begin{array}{l}\text { July 20; RL vs (NR + SR) } \\
\text { Average Squared Distance= } 14.42\end{array}$}} & \multirow{2}{*}{\multicolumn{5}{|c|}{$\begin{array}{l}\text { July 20; DL vs RL } \\
\text { Average Squared Distance = } 13.05\end{array}$}} \\
\hline & & & & & & & & & & & & & & \\
\hline & & & Contribution & Cumulative & & & & Contribution & Cumulative & & & & Contribution & Cumulative \\
\hline Variable & Av.Sq.Dist & Sq.Dist/SD & (\%) & (\%) & Variable & Av.Sq.Dist & Sq.Dist/SD & (\%) & (\%) & Variable & Av.Sq.Dist & Sq.Dist/SD & (\%) & (\%) \\
\hline Wood Cover (\%) & 3.62 & 0.90 & 25.65 & 25.65 & Particle Size & 3.12 & 0.62 & 21.65 & 21.65 & Wood Cover (\%) & 2.71 & 0.89 & 20.76 & 20.76 \\
\hline Penetrability (mm) & 2.36 & 0.97 & 16.68 & 42.34 & Macrophyte Cover (\%) & 2.61 & 0.45 & 18.11 & 39.76 & aRPD (mm) & 2.28 & 0.53 & 17.48 & 38.24 \\
\hline Particle Size & 2.28 & 0.57 & 16.14 & 58.48 & Water Content (\%) & 2.30 & 0.78 & 15.98 & 55.74 & Particle Size & 2.15 & 0.62 & 16.49 & 54.73 \\
\hline Water Content (\%) & 2.18 & 0.73 & 15.42 & 73.9 & Wood Cover (\%) & 2.17 & 0.43 & 15.02 & 70.76 & Macrophyte Cover (\%) & 2.13 & 0.41 & 16.30 & 71.03 \\
\hline aRPD (mm) & 2.04 & 0.49 & 14.43 & 88.33 & Penetrability (mm) & 2.17 & 0.59 & 15.02 & 85.78 & Water Content (\%) & 1.89 & 0.79 & 14.49 & 85.52 \\
\hline Macrophyte Cover (\%) & 1.65 & 0.37 & 11.67 & 100 & $\operatorname{aRPD}(\mathrm{mm})$ & 2.05 & 0.56 & 14.22 & 100 & Penetrability $(\mathrm{mm})$ & 1.89 & 0.78 & 14.48 & 100 \\
\hline
\end{tabular}


Table 5. SIMPER (Similarity Percentages) showing percent contribution (\%) of each nutrient variable (normalized) collected at each quadrat to the dissimilarity in nutrient availability between each location at Cassiar Cannery in Inverness Passage, during 2017. All variables were SQRT(X) transformed. Av. Sq. Dist: Average squared distance. Sq Dis/SD: Ratio of the average squared distance to the standard deviation.

\section{May 30 vs June 21}

Average Squared Distance $=4.96$

\begin{tabular}{ccccc}
\hline Variable & Av.Sq.Dist & Sq.Dist/SD & $\begin{array}{c}\text { Contribution } \\
(\%)\end{array}$ & $\begin{array}{c}\text { Cumulative } \\
(\%)\end{array}$ \\
\hline Chlorophyll $a$ Concentration $\left(\mathrm{mg} / \mathrm{m}^{2}\right)$ & 3.13 & 0.56 & 63.1 & 63.10 \\
Organic Matter Content $(\%)$ & 1.83 & 0.76 & 36.9 & 100 \\
\hline
\end{tabular}

\section{May 30 vs July 20}

Average Squared Distance $=5.18$

\begin{tabular}{ccccc}
\hline Variable & Av.Sq.Dist & Sq.Dist/SD & $\begin{array}{c}\text { Contribution } \\
(\%)\end{array}$ & $\begin{array}{c}\text { Cumulative } \\
(\%)\end{array}$ \\
\hline $\begin{array}{c}\text { Chlorophyll } a \text { Concentration }\left(\mathrm{mg} / \mathrm{m}^{2}\right) \\
\text { Organic Matter Content (\%) }\end{array}$ & 2.89 & 0.57 & 55.7 & 55.70 \\
\hline June 21 vs July 20 & 2.30 & 0.79 & 44.3 & 100 \\
Average Squared Distance $=2.28$ & & & & \\
\hline Variable & & & & \\
\hline Organic Matter Content (\%) & Av.Sq.Dist & Sq.Dist/SD & $\begin{array}{c}\text { Contribution } \\
(\%)\end{array}$ & $\begin{array}{c}\text { Cumulative } \\
(\%)\end{array}$ \\
\hline Chlorophyll $a$ Concentration $\left(\mathrm{mg} / \mathrm{m}^{2}\right)$ & 2.10 & 0.81 & 91.74 & 91.74 \\
\end{tabular}




\section{Supplemental Material}

Table A.1. Mean abundance (individuals $\left./ \mathrm{m}_{2}\right)$ and standard error $(\mathrm{n}=27)$ of the infaunal invertebrate community at four locations at the intertidal Cassiar Cannery mudflat in Inverness Passage during the summer of 2017.

\begin{tabular}{|c|c|c|c|c|}
\hline Species & Location & May 30 & June 21 & July 20 \\
\hline \multirow[t]{4}{*}{ Eogammarus confervicolus } & Dock Location & $0.00 \pm 0.00$ & $0.00 \pm 0.00$ & $0.00 \pm 0.00$ \\
\hline & Resort Location & $0.00 \pm 0.00$ & $0.00 \pm 0.00$ & $28.88 \pm 28.88$ \\
\hline & North Reference & $0.00 \pm 0.00$ & $28.88 \pm 28.88$ & $115.53 \pm 87.84$ \\
\hline & South Reference & $0.00 \pm 0.00$ & $0.00 \pm 0.00$ & $0.00 \pm 0.00$ \\
\hline \multirow[t]{4}{*}{ Americorophium salmonis } & Dock Location & $346.59 \pm 178.63$ & $173.30 \pm 96.87$ & $462.12 \pm 104.14$ \\
\hline & Resort Location & $404.36 \pm 115.53$ & $3,465.90 \pm 1,554.23$ & $2,368.37 \pm 945.65$ \\
\hline & North Reference & $548.77 \pm 222.79$ & $3,985.79 \pm 1,361.77$ & $3,292.61 \pm 832.22$ \\
\hline & South Reference & $173.30 \pm 114.62$ & $1,704.07 \pm 960.10$ & $982.01 \pm 437.07$ \\
\hline \multirow[t]{4}{*}{ Oligochaeta } & Dock Location & $1,646.30 \pm 702.59$ & $3,841.38 \pm 1,170.37$ & $3,379.26 \pm 1,703.46$ \\
\hline & Resort Location & $144.41 \pm 87.84$ & $404.36 \pm 341.44$ & $0.00 \pm 0.00$ \\
\hline & North Reference & $548.77 \pm 152.83$ & $1,299.71 \pm 462.57$ & $231.06 \pm 133.14$ \\
\hline & South Reference & $837.59 \pm 372.13$ & $1,126.42 \pm 354.62$ & $28.88 \pm 28.88$ \\
\hline \multirow[t]{4}{*}{ Nippoleucon hinumensis } & Dock Location & $86.65 \pm 43.32$ & $346.59 \pm 137.00$ & $1,299.71 \pm 794.14$ \\
\hline & Resort Location & $28.88 \pm 28.88$ & $346.59 \pm 178.63$ & $259.94 \pm 86.65$ \\
\hline & North Reference & $57.77 \pm 57.77$ & $664.30 \pm 474.81$ & $202.18 \pm 84.21$ \\
\hline & South Reference & $144.41 \pm 76.42$ & $635.42 \pm 256.71$ & $722.06 \pm 305.66$ \\
\hline \multirow[t]{4}{*}{ Cumella vulgaris } & Dock Location & $404.36 \pm 130.77$ & $86.65 \pm 43.32$ & $28.88 \pm 28.88$ \\
\hline & Resort Location & $57.77 \pm 57.77$ & $28.88 \pm 28.88$ & $202.18 \pm 72.21$ \\
\hline & North Reference & $28.88 \pm 28.88$ & $0.00 \pm 0.00$ & $0.00 \pm 0.00$ \\
\hline & South Reference & $0.00 \pm 0.00$ & $28.88 \pm 28.88$ & $375.47 \pm 241.65$ \\
\hline \multirow[t]{4}{*}{ Abarenicola pacifica } & Dock Location & $0.00 \pm 0.00$ & $57.77 \pm 57.77$ & $0.00 \pm 0.00$ \\
\hline & Resort Location & $0.00 \pm 0.00$ & $0.00 \pm 0.00$ & $0.00 \pm 0.00$ \\
\hline & North Reference & $231.06 \pm 133.14$ & $115.53 \pm 45.67$ & $0.00 \pm 0.00$ \\
\hline & South Reference & $0.00 \pm 0.00$ & $231.06 \pm 146.56$ & $0.00 \pm 0.00$ \\
\hline \multirow[t]{4}{*}{ Capitella Species Complex } & Dock Location & $982.01 \pm 266.28$ & $693.18 \pm 252.62$ & $231.06 \pm 91.33$ \\
\hline & Resort Location & $1,906.25 \pm 872.95$ & $1,617.42 \pm 838.71$ & $1,155.30 \pm 586.25$ \\
\hline & North Reference & $3,956.91 \pm 1,042.28$ & $3,668.08 \pm 1,412.81$ & $3,725.85 \pm 1,670.64$ \\
\hline & South Reference & $1,068.65 \pm 491.00$ & $2,310.60 \pm 1,120.94$ & $404.36 \pm 130.77$ \\
\hline \multirow[t]{4}{*}{ Pygospio elegans } & Dock Location & $1,559.66 \pm 312.41$ & $5,516.56 \pm 2,409.75$ & $2,974.90 \pm 1,324.12$ \\
\hline & Resort Location & $1,906.25 \pm 671.17$ & $2,686.08 \pm 1,271.98$ & $808.71 \pm 339.60$ \\
\hline & North Reference & $2,888.25 \pm 852.77$ & $3,090.43 \pm 845.03$ & $2,195.07 \pm 464.82$ \\
\hline & South Reference & $1,357.48 \pm 902.32$ & $2,512.78 \pm 1,280.80$ & $375.47 \pm 290.98$ \\
\hline \multirow[t]{4}{*}{ Aricidea hartleyi } & Dock Location & $866.48 \pm 528.83$ & $750.95 \pm 507.91$ & $202.18 \pm 112.79$ \\
\hline & Resort Location & $0.00 \pm 0.00$ & $0.00 \pm 0.00$ & $0.00 \pm 0.00$ \\
\hline & North Reference & $0.00 \pm 0.00$ & $0.00 \pm 0.00$ & $28.88 \pm 28.88$ \\
\hline & South Reference & $0.00 \pm 0.00$ & $0.00 \pm 0.00$ & $0.00 \pm 0.00$ \\
\hline \multirow[t]{4}{*}{ Fabricia stellaris } & Dock Location & $0.00 \pm 0.00$ & $317.71 \pm 286.65$ & $0.00 \pm 0.00$ \\
\hline & Resort Location & $0.00 \pm 0.00$ & $0.00 \pm 0.00$ & $0.00 \pm 0.00$ \\
\hline & North Reference & $0.00 \pm 0.00$ & $259.94 \pm 259.94$ & $0.00 \pm 0.00$ \\
\hline & South Reference & $0.00 \pm 0.00$ & $0.00 \pm 0.00$ & $0.00 \pm 0.00$ \\
\hline \multirow[t]{3}{*}{ Eteone californica } & Dock Location & $231.06 \pm 101.09$ & $346.59 \pm 86.65$ & $144.41 \pm 62.95$ \\
\hline & Resort Location & $346.59 \pm 167.79$ & $635.42 \pm 256.71$ & $433.24 \pm 137.00$ \\
\hline & North Reference & $259.94 \pm 106.12$ & $779.83 \pm 324.21$ & $577.65 \pm 166.54$ \\
\hline
\end{tabular}




\begin{tabular}{|c|c|c|c|c|}
\hline & South Reference & $375.47 \pm 130.77$ & $1,444.13 \pm 284.46$ & $433.24 \pm 96.87$ \\
\hline \multirow[t]{4}{*}{ Paranemertes peregrina } & Dock Location & $115.53 \pm 115.53$ & $57.77 \pm 38.21$ & $28.88 \pm 28.88$ \\
\hline & Resort Location & $0.00 \pm 0.00$ & $57.77 \pm 57.77$ & $0.00 \pm 0.00$ \\
\hline & North Reference & $86.65 \pm 43.32$ & $28.88 \pm 28.88$ & $202.18 \pm 84.21$ \\
\hline & South Reference & $86.65 \pm 86.65$ & $28.88 \pm 28.88$ & $0.00 \pm 0.00$ \\
\hline \multirow[t]{4}{*}{ Macoma balthica } & Dock Location & $866.48 \pm 259.94$ & $808.71 \pm 133.14$ & $1,126.42 \pm 327.09$ \\
\hline & Resort Location & $1,357.48 \pm 417.30$ & $433.24 \pm 203.21$ & $577.65 \pm 160.81$ \\
\hline & North Reference & $1,530.77 \pm 388.57$ & $1,473.01 \pm 375.20$ & $837.59 \pm 317.71$ \\
\hline & South Reference & $693.18 \pm 225.12$ & $375.47 \pm 194.29$ & $664.30 \pm 107.10$ \\
\hline \multirow[t]{4}{*}{ Nematoda } & Dock Location & $2,426.13 \pm 556.50$ & $3,783.61 \pm 753.03$ & $4,505.68 \pm 2,086.75$ \\
\hline & Resort Location & $2,888.25 \pm 859.35$ & $2,426.13 \pm 1,118.06$ & $115.53 \pm 45.67$ \\
\hline & North Reference & $2,974.90 \pm 1,749.18$ & $3,437.02 \pm 1,541.97$ & $2,657.19 \pm 1,265.90$ \\
\hline & South Reference & $3,552.55 \pm 707.92$ & $16,636.34 \pm 4,725.87$ & $1,097.54 \pm 904.40$ \\
\hline \multirow[t]{4}{*}{ Harpacticoida } & Dock Location & $57.77 \pm 38.21$ & $288.83 \pm 257.93$ & $115.53 \pm 76.42$ \\
\hline & Resort Location & $404.36 \pm 123.39$ & $317.71 \pm 94.70$ & $519.89 \pm 173.30$ \\
\hline & North Reference & $982.01 \pm 493.54$ & $462.12 \pm 104.14$ & $577.65 \pm 219.96$ \\
\hline & South Reference & $779.83 \pm 293.84$ & $895.36 \pm 372.97$ & $3,696.96 \pm 2,962.78$ \\
\hline \multirow[t]{4}{*}{ Ostracoda } & Dock Location & $28.88 \pm 28.88$ & $0.00 \pm 0.00$ & $28.88 \pm 28.88$ \\
\hline & Resort Location & $0.00 \pm 0.00$ & $0.00 \pm 0.00$ & $28.88 \pm 28.88$ \\
\hline & North Reference & $0.00 \pm 0.00$ & $0.00 \pm 0.00$ & $0.00 \pm 0.00$ \\
\hline & South Reference & $0.00 \pm 0.00$ & $28.88 \pm 28.88$ & $144.41 \pm 87.84$ \\
\hline \multirow[t]{4}{*}{ Chironomidae Larvae } & Dock Location & $0.00 \pm 0.00$ & $0.00 \pm 0.00$ & $86.65 \pm 61.27$ \\
\hline & Resort Location & $57.77 \pm 38.21$ & $144.41 \pm 144.41$ & $115.53 \pm 62.95$ \\
\hline & North Reference & $0.00 \pm 0.00$ & $0.00 \pm 0.00$ & $0.00 \pm 0.00$ \\
\hline & South Reference & $0.00 \pm 0.00$ & $0.00 \pm 0.00$ & $0.00 \pm 0.00$ \\
\hline \multirow[t]{4}{*}{ Isotomidae sp. } & Dock Location & $0.00 \pm 0.00$ & $0.00 \pm 0.00$ & $0.00 \pm 0.00$ \\
\hline & Resort Location & $0.00 \pm 0.00$ & $0.00 \pm 0.00$ & $28.88 \pm 28.88$ \\
\hline & North Reference & $0.00 \pm 0.00$ & $0.00 \pm 0.00$ & $0.00 \pm 0.00$ \\
\hline & South Reference & $0.00 \pm 0.00$ & $0.00 \pm 0.00$ & $0.00 \pm 0.00$ \\
\hline
\end{tabular}


Table A.2. Mean and standard error $(n=27)$ of sediment variables collected at each quadrat at four locations at the intertidal mudflat at Cassiar Cannery in Inverness Passage during the summer of 2017.

\begin{tabular}{|c|c|c|c|c|}
\hline Variable & Location & May 30 & June 21 & July 20 \\
\hline \multirow{4}{*}{ aRPD (mm) } & Dock Location & $1.89 \pm 0.63$ & $2.78 \pm 1.28$ & $0.89 \pm 0.39$ \\
\hline & Resort Location & $1.00 \pm 0.17$ & $0.78 \pm 0.32$ & $4.89 \pm 2.81$ \\
\hline & North Reference & $3.56 \pm 0.99$ & $4.56 \pm 1.26$ & $1.22 \pm 0.15$ \\
\hline & South Reference & $3.44 \pm 2.08$ & $2.78 \pm 0.97$ & $6.00 \pm 2.95$ \\
\hline \multirow{4}{*}{ Macro (\%) } & Dock Location & $0.00 \pm 0.00$ & $0.00 \pm 0.00$ & $0.00 \pm 0.00$ \\
\hline & Resort Location & $2.67 \pm 2.19$ & $3.89 \pm 2.17$ & $7.67 \pm 6.59$ \\
\hline & North Reference & $30.11 \pm 12.24$ & $20.33 \pm 11.47$ & $2.56 \pm 1.62$ \\
\hline & South Reference & $0.22 \pm 0.22$ & $1.78 \pm 1.66$ & $0.00 \pm 0.00$ \\
\hline \multirow{4}{*}{ Particle Size } & Dock Location & $49.44 \pm 1.82$ & $41.83 \pm 4.20$ & $40.98 \pm 3.56$ \\
\hline & Resort Location & $48.33 \pm 3.92$ & $46.43 \pm 6.97$ & $59.94 \pm 11.16$ \\
\hline & North Reference & $46.30 \pm 5.37$ & $40.54 \pm 2.96$ & $37.88 \pm 2.75$ \\
\hline & South Reference & $49.44 \pm 7.63$ & $50.39 \pm 7.51$ & $34.71 \pm 1.86$ \\
\hline \multirow{4}{*}{ Penetrability (mm) } & Dock Location & $41.44 \pm 6.74$ & $47.33 \pm 5.07$ & $38.11 \pm 7.06$ \\
\hline & Resort Location & $27.33 \pm 2.65$ & $26.67 \pm 2.88$ & $37.22 \pm 5.09$ \\
\hline & North Reference & $43.11 \pm 2.28$ & $37.89 \pm 2.91$ & $39.67 \pm 4.00$ \\
\hline & South Reference & $31.44 \pm 4.21$ & $35.67 \pm 3.90$ & $44.67 \pm 3.82$ \\
\hline \multirow{4}{*}{ Water Content (\%) } & Dock Location & $34.87 \pm 1.12$ & $35.98 \pm 1.17$ & $34.56 \pm 1.38$ \\
\hline & Resort Location & $32.97 \pm 0.95$ & $33.12 \pm 0.82$ & $34.23 \pm 1.62$ \\
\hline & North Reference & $35.80 \pm 1.47$ & $34.81 \pm 1.18$ & $36.84 \pm 1.58$ \\
\hline & South Reference & $35.33 \pm 1.08$ & $34.04 \pm 1.06$ & $37.06 \pm 0.87$ \\
\hline \multirow{4}{*}{ Wood Cover (\%) } & Dock Location & $22.33 \pm 10.41$ & $33.89 \pm 9.64$ & $23.89 \pm 9.27$ \\
\hline & Resort Location & $1.78 \pm 1.16$ & $1.33 \pm 0.60$ & $0.11 \pm 0.11$ \\
\hline & North Reference & $0.00 \pm 0.00$ & $0.22 \pm 0.15$ & $0.11 \pm 0.11$ \\
\hline & South Reference & $0.44 \pm 0.24$ & $0.89 \pm 0.89$ & $0.00 \pm 0.00$ \\
\hline
\end{tabular}


Table A. 3. Mean and standard error $(n=27)$ of nutrient variables measured at each quadrat at four locations at the intertidal mudflat at Cassiar Cannery in Inverness Passage during the summer of 2017.

\begin{tabular}{ccccc}
\hline Variable & Location & May 30 & June 21 & July 20 \\
\hline & Dock Location & $14.37 \pm 9.16$ & $0.59 \pm 0.44$ & $0.75 \pm 0.18$ \\
Chlorophyll $a$ & Resort Location & $7.31 \pm 6.82$ & $0.85 \pm 0.50$ & $1.05 \pm 0.48$ \\
Concentration $\left(\mathrm{mg} / \mathrm{m}_{2}\right)$ & North Reference & $20.66 \pm 10.33$ & $0.79 \pm 0.43$ & $1.15 \pm 0.25$ \\
& South Reference & $13.84 \pm 8.99$ & $0.53 \pm 0.23$ & $0.63 \pm 0.17$ \\
& Dock Location & $4.07 \pm 0.22$ & $4.05 \pm 0.13$ & $4.20 \pm 0.18$ \\
Organic Matter Content & Resort Location & $3.95 \pm 0.14$ & $3.78 \pm 0.12$ & $4.11 \pm 0.16$ \\
$(\%)$ & North Reference & $3.76 \pm 0.19$ & $3.66 \pm 0.13$ & $4.01 \pm 0.19$ \\
& South Reference & $4.07 \pm 0.17$ & $3.73 \pm 0.11$ & $4.38 \pm 0.15$ \\
\hline
\end{tabular}

